AperTO - Archivio Istituzionale Open Access dell'Università di Torino

\title{
Water content and nature of solutes in shallow-mantle fluids from fluid inclusions
}

\section{This is the author's manuscript}

Original Citation:

Availability:

This version is available http://hdl.handle.net/2318/118370

since

Published version:

DOI:10.1016/j.epsl.2012.07.023

Terms of use:

Open Access

Anyone can freely access the full text of works made available as "Open Access". Works made available under a Creative Commons license can be used according to the terms and conditions of said license. Use of all other works requires consent of the right holder (author or publisher) if not exempted from copyright protection by the applicable law. 


\section{UNIVERSITÀ DEGLI STUDI DI TORINO}

This Accepted Author Manuscript (AAM) is copyrighted and published by Elsevier. It is posted here by agreement between Elsevier and the University of Turin. Changes resulting from the publishing process - such as editing, corrections, structural formatting, and other quality control mechanisms may not be reflected in this version of the text. The definitive version of the text was subsequently published in Earth and Planetary Science Letters, 351-352, 2012, doi: 10.1016/j.epsl.2012.07.023.

You may download, copy and otherwise use the AAM for non-commercial purposes provided that your license is limited by the following restrictions:

(1) You may use this AAM for non-commercial purposes only under the terms of the CC-BY-NC-ND license.

(2) The integrity of the work and identification of the author, copyright owner, and publisher must be preserved in any copy.

(3) You must attribute this AAM in the following format: Creative Commons BY-NC-ND license (http://creativecommons.org/licenses/by-nc-nd/4.0/deed.en), doi: 10.1016/j.epsl.2012.07.023 
Water content and nature of solutes in shallow-mantle fluids from fluid inclusions

$6 \quad{ }^{1}$ Department of Earth Sciences, University of Siena, Via Laterina 8, 53100 Siena, Italy.

7 marialuce.frezzotti@unisi.it; Tel. +39 0577 233929; Fax +390577 233938.

$8{ }^{2}$ Department of Earth Sciences, University of Torino, Via V. Caluso 35, 10125 Torino, Italy.

9 simona.ferrando@unito.it; daniele.castelli@unito.it

$10{ }^{3} \mathrm{IGAG}$ - CNR, c/o Department of Earth Sciences, University of Rome "La Sapienza”, P.za A. Moro 5,

1100185 Roma, Italy. francesca.tecce@cnr.it 


\section{Abstract}

This study discusses new and published data on the composition of fluid inclusions contained in mantle minerals of spinel and garnet peridotite xenoliths, in samples from geodynamically distinct settings (Ethiopian plateau, Hawaii, Canary Islands, and western Mediterranean region). Based on spectroscopic Raman and FTIR analyses we show that, contrary to a commonly held view, fluid inclusions either contain relevant amounts of unsuspected $\mathrm{H}_{2} \mathrm{O}$, or represent a "dehydrated" composition from multicomponent aqueocarbonic fluids. We identify water loss from fluid inclusions through decrepitation, stretching and hydrogen diffusion. We also show that talc, magnesite, chlorides, and sulfates represent common phases in fluid inclusions. Talc and magnesite form through reactions of fluids with the surrounding minerals. Thermodynamic modeling in the MFSHC system of observed reactions between fluid inclusions and surrounding mantle minerals provides the basis for predicting water amounts in shallow-mantle fluids, and suggests $\mathrm{X}_{\mathrm{H} 2 \mathrm{O}}$ in the range of $10-50$ mole $\%$. Model hydrous fluids are relatively enriched solutions, dominated by $\mathrm{Si}, \mathrm{Cl}$, and alkalies, with significant $\mathrm{Ca}$, and $\mathrm{S}$, and low $\mathrm{Mg}$ and $\mathrm{Fe}$. This study argues that multicomponent hydrous fluids may be widespread in the shallow mantle, not only in subduction zones but also in intraplate and extensional settings.

Keywords: Mantle petrology, Upper mantle fluid, fluid inclusions, Raman spectroscopy, FT-IR spectroscopy 


\section{Introduction}

The volatile (e.g., C, O, H and halogens) inventory in the Earth's upper mantle includes accessory phases, nominally anhydrous minerals (NAMS), along with mobile fluid phases and volatile-rich melts (e.g., Bell et al., 2003; Bolfan-Casanova et al., 2000; Dasgupta and Hirschmann, 2006; Green and Falloon, 1998; Thompson, 1992; Wyllie and Ryabchikov, 2000). Hydrous fluids are critical to understand the structure and dynamics of the upper mantle, as they play a major role during deformation and recrystallization processes, and control partial melting of peridotites in upwelling mantle (Asimow and Langmuir, 2003; Dixon et al., 2004; Hirth and Kohlstedt, 2003; Katayama and Karato, 2008; Katz, et al., 2003). Furthermore, water has a major control on the oxidation state and on the selective enrichment in alkalies, large ion lithophile elements (LILE), and light rare earth elements (LREE) of mantle rocks (Bailey, 1982; Dixon et al., 2002; Kessel et al., 2005). Despite considerable progresses in modeling fluid behavior, our understanding of the exact nature and composition of hydrous mantle fluids is hampered by the absence of distinctive chemical signatures in many peridotites.

C-O-H fluid speciation is largely dependent on oxygen fugacity $\left(f \mathrm{O}_{2}\right) . \mathrm{H}_{2} \mathrm{O}$ and $\mathrm{CO}_{2}$ are predicted to be the major fluid components in the shallow mantle at $P \leq 2-3 \mathrm{GPa}$, for $f \mathrm{O}_{2}$ equal to or greater than the quartz-fayalite-magnetite buffer (QFM) (Connolly, 1995; French, 1966; Huizenga, 2001, 2005; Ohmoto and Kerrick, 1977; Shi and Saxena, 1992; Zhang and Duan, 2009, 2010). Studies of gasses contained in or released from magmas, and of accessory mantle minerals (e.g., phlogopite, amphibole and apatite) suggest that fluids should contain $\mathrm{CO}_{2}, \mathrm{H}_{2} \mathrm{O}$, and halogens (Marty and Tolstikhin, 1998; Marty and Zimmermann, 1999; Murck et al., 1978; Oppenheimer et al., 2011; O’Reilly and Griffin, 2000; Patino Douce et al., 2011; Smith et al., 1981; Wallace, 2003).

Fluid inclusions are the best natural samples to provide evidence for the nature of shallowmantle fluids. However, we have known for a long time that fluid inclusions in peridotites are 
typically $\mathrm{CO}_{2}$-rich relative to other volatiles (cf. reviews by Andersen and Neumann, 2001; Pasteris, 1987; Roedder, 1965; 1984). This discrepancy between the fluid composition observed in inclusions and that predicted by oxy-thermobarometry has bolstered models that suggest any mobile hydrous component to be partitioned to melt phases, such as silicate and carbonate melts (e.g., Luth, 2003; Murck et al., 1978; Thompson, 1992). Consequently, the apparent absence of $\mathrm{H}_{2} \mathrm{O}$ has undermined the credibility of fluid inclusions as tracers of mantle processes, and has brought some authors to propose that most fluid inclusions represent late features, mainly related to deep magma degassing during ascent of peridotite xenoliths (e.g., Pasteris, 1987).

A full survey of fluid inclusions in mantle rocks does not fit the view of "pure" $\mathrm{CO}_{2}$ fluids well. For example, Andersen et al. (1984) first proposed $\mathrm{CO}_{2}$-brine fluids in peridotites from extensional mantle settings based on the association of carbonate and chlorine-bearing amphibole in $\mathrm{CO}_{2}$ inclusions in peridotites from Bullenmeri (SE Australia). Similarly, Frezzotti et al. (2002a, and b) suggested that aggregates of talc and $\mathrm{NaCl}$ lining $\mathrm{CO}_{2}$ inclusion cavities in olivine from peridotite of Tenerife (Canary Islands) formed as the result of post-entrapment chemical reaction between $\mathrm{CO}_{2}$-brine fluids and the surrounding minerals. Recently, $\mathrm{H}_{2} \mathrm{O}$ has been detected in deep diamond-bearing $\mathrm{CO}_{2}$-rich fluid inclusions in garnet pyroxenites from Oahu, Hawaii (Frezzotti and Peccerillo, 2007). In addition, brine inclusions have been described in peridotites from subduction-zone settings with increasing frequency (e.g., Hidas et al., 2010; McInnes et al., 2001; Scambelluri et al., 1997; Trial et al., 1984).

This study is aimed to check for the presence of water in fluid inclusions formed at mantle depths in several suites of metasomatized peridotite xenoliths from the Ethiopian plateau,

Hawaii, and the western Mediterranean region, using Raman and Fourier transform infrared (FTIR) microspectroscopies. We compare the present results with the results of previously published studies and critically reevaluate the composition of fluid phases at shallow-mantle depths. The present study documents that there is, or there was, a hydrous solute-rich hydrous component in 
many mantle fluids trapped as inclusions. A thermodynamic model to evaluate the $\mathrm{H}_{2} \mathrm{O}$ budget in shallow-mantle fluids is proposed. Although the present study focuses on mantle rocks, our approach is equally applicable to eclogites, migmatites, and granulites in the lower continental crust, where hydrous fluids are often predicted but not observed in fluid inclusions (e.g.,

Hollister, 1990; Touret, 1981, 2001).

\section{Description of studied samples}

We have investigated fluid inclusions in several suites of metasomatized spinel and garnet peridotite xenoliths. Rocks were selected from intraplate or extensional tectonic settings related recent to Plio-Quaternary volcanism. Our goal was to focus on fluid inclusions formed at mantle depths in order to study the composition of mobile mantle fluid phases. For this reason, we selected those peridotites which did not show significant melt infiltration, and where fluid inclusions did not contain glass (i.e., volatile-rich melts). Fluid inclusions were analyzed in olivine, orthopyroxene and clinopyroxene. Studied peridotites and fluid inclusions are described in the following paragraphs and presented in Table 1.

Six pargasite-bearing spinel lherzolites were selected from a suite of peridotites in Quaternary basanitic lavas from a cinder cone located in the Lake Tana region, part of the Ethiopian Plateau (Ferrando et al., 2008; Table 1). Rocks show protogranular to porphyroclastic textures and equilibrated in the lithosphere at $950-1015^{\circ} \mathrm{C}$ and 1.3-2.0 GPa (Ferrando et al., 2008). Peridotites contain $\mathrm{Cl}$-rich pargasite, and cryptic enrichments in $\mathrm{Fe}, \mathrm{Al}, \mathrm{LILE}$ and $\mathrm{Pb}$ are observed in clinopyroxene (Frezzotti et al., 2010). Coeval $\mathrm{CO}_{2}$-rich fluid inclusions tiny (5-30 $\mu \mathrm{m})$ occur in olivine and orthopyroxene porphyroclasts and subordinately in clinopyroxene, along short intragranular trails. Orthopyroxene is rich in fluid inclusions and preserves the highest density fluids (Table 1). Liquid water was detected in three $\mathrm{CO}_{2}$-rich inclusions in 
orthopyroxene and olivine under the microscope and the heating-freezing stage. From these observations, the estimated fluid composition is $\mathrm{X}_{\mathrm{CO} 2}=0.64, \mathrm{X}_{\mathrm{H} 2 \mathrm{O}}=0.33, \mathrm{X}_{\mathrm{Na}}=0.006, \mathrm{X}_{\mathrm{Mg}}=$ 0.006, $\mathrm{X}_{\mathrm{Cl}}=0.018$, and the calculated isochores indicate trapping pressures, $P$, of 1.4-1.5 GPa, at $950{ }^{\circ} \mathrm{C}$ (Table 1). Modeled fluid composition is in agreement with the formation of Cl-rich metasomatic hydrous phases and with metasomatic enrichments in clinopyroxenes (Frezzotti et al., 2010). High $\mathrm{Cl}$, LILE, and $\mathrm{Pb}$ in model metasomatic fluid phases point to a contribution of recycled altered oceanic lithosphere component in their source.

Four garnet pyroxenite samples were borrowed from the Jackson collection (Jackson and Wright, 1970) of the National Museum of Natural History (Washington D.C., USA). These are from alkali-post erosional stage Honolulu volcanics (< 1 m.y.) at Salt Lake Crater (SLC), Koolau shield, in the Island of Oahu, Hawaii (Clague and Frey, 1982; Lassiter at al., 2000; Sen, 1988). SLC garnet pyroxenites show coarse granular textures and consist of clinopyroxene (diopsideaugite; > $60 \% \mathrm{vol}$ ), olivine, orthopyroxene, garnet, and spinel. Garnet is of secondary origin, and mainly formed through exsolution from pyroxene during recrystallization processes. Although amphibole and phlogopite were previously reported (cf., Sen, 1988), traces of phlogopite were observed only in one sample. SLC garnet pyroxenites were interpreted as crystal cumulates from the recent Hawaiian volcanism in the Pacific lithosphere $(P=1.6-2.2 \mathrm{GPa})$. Recent reports of majoritic garnet and of microdiamonds imply a much deeper origin (ca. 4.5-5 GPa; Frezzotti and Peccerillo, 2007; Keshav and Sen, 2001, 2003; Keshav et al., 2007; Wirth and Rocholl, 2003). According to Keshav et al. (2007), garnet pyroxenites represent highpressure cumulates related to polybaric magma fractionation in the asthenosphere. Early highdensity to superdense $\mathrm{CO}_{2}\left(\mathrm{~d}=1.16-1.21 \mathrm{~g} / \mathrm{cm}^{3}\right)$ fluid inclusions $(\leq 5-6 \mu \mathrm{m})$ occur in clinopyroxene and subordinately in orthopyroxene, generally distributed along (010) directions. Superdense $\mathrm{CO}_{2}$ is recognized by initial melting at the temperature of partial homogenization to liquid $\left(-56.6^{\circ} \mathrm{C}\right.$; ThLs); final melting (TsL) occurs at temperatures up to $-50.8^{\circ} \mathrm{C}$ (Table 1 ; Frezzotti et al., 1992). Early inclusions contain microdiamonds and traces of $\mathrm{H}_{2} \mathrm{O}, \mathrm{N}_{2}$ and $\mathrm{H}_{2} \mathrm{~S}$ 
(Frezzotti and Peccerillo, 2007), but no glass/melt. Rare carbonate inclusions, and mixed $\mathrm{CO}_{2}+$ carbonate \pm diamond inclusions have also been observed. These characteristics are consistent with a genetic link of fluids with ephemeral carbonate-rich melt generated in the asthenosphere within the diamond stability field (Frezzotti and Peccerillo, 2007).

Four spinel phlogopite-harzburgites and one dunite from central Italy occur in lamproitic lavas of Torre Alfina volcano (0.9-0.8 M.y.; Conticelli and Peccerillo 1990). Xenoliths consist of olivine and subordinate (3-12 vol. \%) orthopyroxene porphyroclasts showing protogranular textures (Table 1). Rare anhedral clinopyroxene occurs in the interstices between deformed olivines. Brownish to black spinels are also present as isolated coarse crystals $(>1 \mathrm{~mm})$ or as smaller grains. Metasomatic phlogopite is present in amounts variable from less than 1 up to $10 \%$ of the rock by mode. This has $\mathrm{Sr}-\mathrm{Nd}\left({ }^{87} \mathrm{Sr} /{ }^{86} \mathrm{Sr} \sim 0.716-0.717 ;{ }^{143} \mathrm{Nd} /{ }^{144} \mathrm{Nd} \sim 0.5121\right)$ isotopic signatures close to those of the host lamproites (Conticelli, 1998). Geothermobarometric studies indicate equilibrium pressures, $P$, of ca. 1.2-1.6 GPa, corresponding to a depth of 50 to $60 \mathrm{~km}$, and temperatures, $T$, of $950-1080{ }^{\circ} \mathrm{C}$ (Pera et al., 2003; unpublished data). Rare $\mathrm{CO}_{2}$-rich fluid inclusions are observed only in a few orthopyroxene porhyroclasts. Inclusions are tiny $(\leq 5 \mu \mathrm{m})$ and distributed along (010) directions.

Mantle melting and generation of lamproites took place during opening of Western Mediterranean basins, after the Europe-Africa continental collision. Central Italian peridotites represent samples of a "hot" lithosphere, located close to the asthenosphere-lithosphere boundary (Frezzotti et al., 2009). Metasomatism involved the presence of subducted fluids/melts of continental origin related to older subduction events of Alpine age (Peccerillo, 2005, and references therein).

Three spinel dunites and two spinel pyroxenites from Sardinia are from the spatter cone of Monte Lisiri volcano ( 0.9-0.1 Ma; Lustrino et al., 2000), near the village of Ittireddu in the Logudoro region, which is part of the recent Plio-Pleistocene anorogenic alkaline mafic volcanism in northern Sardinia. Dunites show porphyroclastic textures and consist mostly of olivine porphyroclasts, with very subordinate orthopyroxene and undeformed interstitial clinopyroxene 
grains. Granular pyroxenites are dominated by clinopyroxene (> 85 vol. \%), with subordinate olivine and orthopyroxene. Mineral thermometry indicates relatively low temperatures $\left(950^{\circ} \mathrm{C}\right)$. In pyroxenites, modal metasomatism is testified by the presence of phlogopite (1-2 vol. \%) with high $\mathrm{Cl}$ contents (ca. 0.4-0.5 wt \%). In dunites and pyroxenites, intragranular trails of $\mathrm{CO}_{2}$-rich fluid inclusions tiny $(5-20 \mu \mathrm{m})$ are abundant in orthopyroxene and clinopyroxene, the highest $\mathrm{CO}_{2}$ densities being recorded in clinopyroxene (Table 1). In Sardinia, the origin of pyroxenites has been related to deep cumulus processes, whereas peridotites have been interpreted as upper mantle residues variably affected by metasomatic processes by melts derived from partial melting of lower crustal rocks (Lustrino et al., 2000; 2004). Peccerillo (2005), however, did not exclude that metasomatism of the lithosphere beneath northern Sardinia might have occurred by subductionrelated fluids or melts in Oligo-Miocene times, based on composition of mafic rocks.

Among selected samples, pyrope garnet is present only in Hawaiian pyroxenites, and it does not contain mantle fluid inclusions. In order to study the post-entrapment evolution of fluid inclusions in garnet, we additionally included one sample of whiteschist from the Dora Maira Massif in western Alps (Italy), a slice of continental crust that experienced subduction to ultrahigh pressure conditions $\left(\mathrm{P}=3.5 \mathrm{GPa}, \mathrm{T}=750^{\circ} \mathrm{C}\right)$ (e.g., Ferrando et al., 2009, and references therein). Abundant aqueous fluid inclusions have been previously described in pyrope from these lithologies (Ferrando et al., 2009; Philippot and Selverstone, 1991).

\section{Analytical Methods}

Raman spectra of minerals and fluid inclusions containing $\mathrm{C}$ and $\mathrm{H}$ were acquired with a Labram microspectrometer (HORIBA Jobin Yvon) at the University of Siena. A polarized 514.5 $\mathrm{nm}$ water-cooled Ar-ion laser was used as the excitation source. The measured laser power was $300-500 \mathrm{~mW}$ at the source, and about $80 \%$ less at the sample surface. Raman spectra were collected through an OLYMPUS 100x objective (0.9 numerical aperture: excitation spot $1 \times 1 \times 5$ 
$\mu \mathrm{m}$ in volume) for an acquisition time variable from $30 \mathrm{~s}$ to $180 \mathrm{~s}$ for each spectrum, and 1 to 10 accumulations. The slit width was set at $100 \mu \mathrm{m}$, and the corresponding spectral resolution was $1.5 \mathrm{~cm}^{-1}$. Frequency wavenumbers of the Raman modes in the region $0-1800 \mathrm{~cm}^{-1}$ were calibrated daily by the position of the diamond peak at $1331.7 \mathrm{~cm}^{-1}$. Peak assignment of solid, gaseous, and liquid phases was done by comparison with our reference library and database of

Raman spectra (http://www.dst.unisi.it/geofluids/raman/spectrum frame.htm; Frezzotti et al., 2012). performed through scanning electron microscopy (SEM; Philips XL30) at the University of Siena. This instrument is equipped with an energy-dispersive spectrometer (EDS-Philips EDAX DX4). Selected doubly polished sections containing fluid inclusions were broken after immersion in liquid nitrogen. Broken samples were immediately mounted on stubs and carbon coated. Operating conditions were as follows: accelerating voltage $20 \mathrm{kV}$, beam current 23-25 $\mu \mathrm{A}$, working distance 10-12 mm. Element maps with the theoretical inner pattern were obtained using the ZAF method of correction. Natural silicates and oxides have been used as standards.

To reveal water diffusion from fluid inclusions into the structure of surrounding minerals, we mapped the distribution -and concentrations of structurally_bound hydrogen in nominally anhydrous minerals by synchrotron based FT-IR microspectroscopy. We selected those mantle minerals where liquid $\mathrm{H}_{2} \mathrm{O}$ was proven in fluid inclusions: olivine and pyroxenes from Ethiopian peridotite xenoliths (Frezzotti et al., 2010), and garnet from Dora Maira whiteschists (Ferrando et al., 2009). Analyses were performed by Fourier transform infrared (FT-IR) microspectroscopy at the infrared beam-line SISSI (Source for Imaging and Spectroscopic Studies in the Infrared) operating at the synchrotron laboratory ELETTRA in Trieste. Spectra were collected on a FTIR spectrometer (Bruker IFS66/v) fitted with a Hyperion IR microscopy with a liquid-nitrogencooled $\mathrm{HgCdTe}$ (MCT) detector. Infrared microscopy was performed on an infrared microscopy system (Bruker) with a 16× magnification infrared objective. Spectra were collected at resolution 
of $4 \mathrm{~cm}^{-1}$ and signal averaged for 128 scans on each data collection. Background spectra were recorded in air. For IR imaging studies, we used double-polished thick sections of xenoliths of known thickness. The spectral images were collected scanning areas of variable sizes (200-450 $\mu \mathrm{m}$-long and 200-450 $\mu \mathrm{m}$-wide), following a regular grid of square-aperture dimension of $20 \mu \mathrm{m}$ equidistant by $20 \mu \mathrm{m}$ in both directions (i.e., totals of 100-400 spectra), using a computercontrolled automated X-Y mapping stage. Interpretation of unpolarized spectra of $\mathrm{H}_{2} \mathrm{O}$ followed the classical group frequency approach in which absorption bands are assigned to specific vibrational modes. $\mathrm{OH}$ concentrations in mineral phases were estimated from the integrated absorbance using the Beer-Lambert law (Paterson, 1982). Experimentally determined calibration constants for orthopyroxene are from Bell et al. (1995), and for olivine are from Bell et al. (2003). Since unpolarized FT-IR $\mathrm{H}_{2} \mathrm{O}$ measurements are affected by large errors (30-50 \%; cf., Demouchy et al., 2006), and imaging revealed $\mathrm{H}$ variations with position within single minerals, measured water contents are reported in intervals of tens of ppm, emphasizing the relative variations with distribution within single grains. Note that, liquid $\mathrm{H}_{2} \mathrm{O}$ and/or hydrous minerals in fluid inclusions were also suggested by FT-IR absorption bands. However, spectra are not reported in the present paper, since we consider FT-IR microspectroscopy a less reliable diagnostic technique than Raman, because of its poorer resolution, and absence of confocality.

Petrogenetic grids were calculated in the $\mathrm{MgO}-\mathrm{FeO}-\mathrm{SiO}_{2}-\mathrm{H}_{2} \mathrm{O}-\mathrm{CO}_{2}(\mathrm{MFSHC})$ model system using the thermodynamic approach of Connolly (1990) and the internally consistent thermodynamic data set and equation of state for $\mathrm{H}_{2} \mathrm{O}-\mathrm{CO}_{2}$ of Holland and Powell (2011), modified considering a typical mantle \#mg $\left[\mathrm{Mg} /\left(\mathrm{Mg}+\mathrm{Fe}^{2+}\right)=0.9\right]$ for olivine and orthopyroxene. 


\section{Results}

Water in $\mathrm{CO}_{2}$-rich fluid inclusions is traditionally revealed by optical studies, although identification may be difficult in dense and often colored mantle minerals (cf., Roedder, 1972). Water can be detected simply by using Raman and FT-IR spectroscopic techniques (cf., Frezzotti and Peccerillo, 2007; Hidas et al., 2010; McMillan et al., 1996, and references therein). Results are given in Table 2 and discussed in the following sections. Note that the potential of Raman microspectroscopy for identifying water in mantle fluid inclusions has been known since the 80's (e.g., Pasteris and Wanamaker, 1988). However, researchers failed to detect $\mathrm{H}_{2} \mathrm{O}$ in fluid inclusions at that time, probably because of the non-confocality and lower sensitivity of old instruments.

\subsection{Uncovering aqueous fluids inside inclusions: Raman spectroscopy and EDAX-EDS analyses}

In almost all studied fluid inclusions $\mathrm{H}_{2} \mathrm{O}$ in not visible. One exception is represented by a few relatively-large fluid inclusions $(>20-30 \mu \mathrm{m})$ in orthopyroxene of spinel lherzolites from the Ethiopian plateau, where thin $(\leq 1 \mu \mathrm{m})$ liquid water films were recognized. In these inclusions, presence of $\mathrm{H}_{2} \mathrm{O}$ was confirmed by clathrates melting during microthermometric studies at low temperatures (Table 2).

Raman microspectroscopy revealed the presence of liquid water in a minority of optically "pure" $\mathrm{CO}_{2}$ fluid inclusions (10-30 $\mu \mathrm{m}$ in size), for which pyroxenes were the enclosing minerals, and a hydrous nature was recognized for the host mantle peridotites (e.g., Ethiopian plateau and Central Italy; Table 2 and Fig. 1a). For example, a Raman spectrum of liquid $\mathrm{H}_{2} \mathrm{O}$ is reported in Figure 1b. The characterizing feature consists of a broad band centered approximately at $3400-3450 \mathrm{~cm}^{-1}$ in the $\mathrm{OH}$ stretching region from 2900 to $3800 \mathrm{~cm}^{-1}$. In those fluid inclusions of less than $5 \mu \mathrm{m}$ in size, a water film rimming the $\mathrm{CO}_{2}$ does not generate a discernible liquid $\mathrm{H}_{2} \mathrm{O}$ Raman spectrum. However, Raman detection of $\mathrm{H}_{2} \mathrm{O}$ was possible also in 
these cases by spectra of isolated $\mathrm{H}_{2} \mathrm{O}$ molecules dissolved in the $\mathrm{CO}_{2}$ fluid (Table 2; Frezzotti and Peccerillo, 2007).

A coat of hydrous silicates and/or carbonates distributed along the rims of fluid inclusions was more commonly identified in place of molecular $\mathrm{H}_{2} \mathrm{O}$ (Table 2; Fig 2 a-d). Talc (Tlc) was recognized by its band distribution in the $\mathrm{OH}^{-}$region at $3677 \mathrm{~cm}^{-1}$ (Fig. 2f). More rarely, band distribution at 3450, 3638, $3673 \mathrm{~cm}^{-1}$ was observed, which corresponds to Mg-chlorite $\left(\mathrm{Mg}_{5} \mathrm{AlSi}_{3} \mathrm{AlO}_{10}(\mathrm{OH})_{8}\right.$; not shown). Magnesite (Mgs) was identified by its diagnostic Raman modes at 1092,738 , and $328 \mathrm{~cm}^{-1}$ (Fig. 2e). Whereas the presence of carbonates in fluid inclusions was revealed by optical microscopy (Fig. 2c and d), talc and chlorite were generally overlooked. The type and amount of minerals lining $\mathrm{CO}_{2}$-rich inclusions depend mainly on the nature of the surrounding mineral (Table 2). In olivine, hydrous silicates and carbonates are common phases (Fig. 2b and c), and in a few cases completely fill the inclusions, without any fluid left (Fig. 2d). Conversely, in orthopyroxene and clinopyroxene, while carbonates are common, hydrous silicate minerals are less frequent (Fig. 2a).

Morphological observations by SEM images inside opened fluid inclusions showed that talc is constituted by very fine flakes, forming micrometer-sized packages distributed parallel to the enclosing mineral phase along the inclusions cavity walls (Fig. 3a and b). Talc and magnesite are often glazed by a thin coating, probably precipitated during opening of fluid inclusions (Fig. 3b). SEM-EDAX spectra indicate that the coating consists of $\mathrm{Ca}, \mathrm{Cl}, \mathrm{S}, \mathrm{K}$, and minor $\mathrm{Si}, \mathrm{Na}, \mathrm{Al}$ and Fe (Fig. 3c). Ca and S correspond to gypsum (Raman analysis, Fig. 3d and e). Other elements suggest the presence of $\mathrm{KCl}, \mathrm{NaCl}$, and probably $\mathrm{SiO}_{2}$ and $\mathrm{Fe}-\mathrm{Al}$ oxides (Fig. 3c-e).

In clinopyroxene from hydrous peridotites (Table 1), EDS-EDAX analyses showed that $\mathrm{CO}_{2}$-rich inclusions occur in contact with a euhedral hydrous mineral, similar in size and chemically identical to the metasomatic phase present in the rocks: pargasite in peridotites from the Ethiopian plateau (Fig. 4a and c), and phlogopite in peridotites from Sardinia (Italy) (Fig. 4b and d). 
Mapped hydrogen gradients in olivine, orthopyroxene and garnet revealed the change from molecular water in the fluid inclusions to $\mathrm{OH}^{-}$bonds in the surrounding anhydrous minerals. Figure 5 reports the FT-IR synchrotron map of orthopyroxene and garnet hosting several fluid inclusion trails (f.i. in Fig. 5a and c). In orthopyroxene, the mapped sample area is 450x450 $\mu \mathrm{m}$ (for a total of 180 spectra), and the $\mathrm{x}-\mathrm{y}$ spatial resolution is $20 \mathrm{x} 20 \mu \mathrm{m}$ (on the order of the inclusion size). The FT-IR map in Fig. 5b clearly shows an exponential increase of bonded hydrogen approaching the inclusion region. The increase of hydrogen content is evident from symmetrical differently colored haloes in orthopyroxene: calculated $\mathrm{H}_{2} \mathrm{O}$ contents range from about 50-100 ppm far from fluid inclusions (more than $100 \mu \mathrm{m}$ ) to about 400-600 ppm, close to fluid inclusions. In garnet (mapped area 400x400 $\mu \mathrm{m}$; x-y resolution 20x20 $\mu \mathrm{m}$ ), we observed a four- to fivefold enrichment of water in areas close to fluid inclusions (Fig. 5d). Hydrogen gradients recorded by map contours represent actual water content variations in garnet with the exception of the fluid inclusion trail area where water contents above $180-200 \mathrm{ppm}$ in part result from a contribution of molecular $\mathrm{H}_{2} \mathrm{O}$ from the inclusions (red to pink areas in Fig. 5d).

In olivine (Fig. 6a; mapped area 280x280 $\mu \mathrm{m}$; x-y resolution 20x20 $\mu \mathrm{m}$ ), water enrichment is less significant than in orthopyroxene and garnet. FT-IR maps in figures $6 \mathrm{~b}$ and $\mathrm{c}$ show the distribution of $\mathrm{OH}^{-}$absorption bands in two separate regions: $3000-3600 \mathrm{~cm}^{-1}$ corresponding to $\mathrm{OH}^{-}$in olivine (Fig. 6b), and 3600-3800 $\mathrm{cm}^{-1}$ corresponding to $\mathrm{OH}^{-}$in serpentine or talc (Fig. 6c; Khisina et al., 2001). The distribution of the strongest absorbance peak of water migration points to hydrogen diffusion from single fluid inclusions into the surrounding olivine. Presence of talc or serpentine close to fluid inclusion trails further suggest that hydration reactions occurred not only inside fluid inclusions but also in surrounding olivine (Fig. 6b).

In clinopyroxene, water enrichments close to fluid inclusion trails were not observed. 


\section{Discussion}

\subsection{There was water in fluid inclusions formed at shallow-mantle depths}

The present study highlights significant dehydration of shallow-mantle fluids after trapping as inclusions. Diffusive loss of $\mathrm{H}_{2} \mathrm{O}$ due to re-equilibration between the inclusion and host is demonstrated by the strong FT-IR absorbance peak of water migration in the host nominally anhydrous mantle minerals. Transport of water could have occurred under conditions of differential pressures and fluid fugacity at high $P$ and $T$ through lattice defects and microfractures. A high-concentration of dislocations around fluid inclusions was previously reported in olivine from Canary Islands peridotites, and was proposed to be the main mechanism for molecular fluid loss (Viti and Frezzotti, 2000; 2001). This diffusion-scenario is conceivable considering the extremely fast diffusion of $\mathrm{H}$ in olivine (Mackwell and Kohlstedt, 1990), and reinforces models proposed for selective $\mathrm{H}_{2} \mathrm{O}$ loss from $\mathrm{CO}_{2}-\mathrm{H}_{2} \mathrm{O}$ inclusions in quartz (Bakker and Jansen, 1991; Romer et al., 2006; Sterner and Bodnar, 1989; Watson and Brenan, 1987).

Further, dehydration of mantle fluids is induced by reactions between residual $\mathrm{H}_{2} \mathrm{O}$ fluids in the inclusions and the surrounding minerals. In magnesian olivine, the association of talc and magnesite may form at low $T$ and $P$ through the following reaction:

$$
4 \mathrm{Mg}_{2} \mathrm{SiO}_{4}+\mathrm{H}_{2} \mathrm{O}+5 \mathrm{CO}_{2}=\mathrm{Mg}_{3} \mathrm{Si}_{4} \mathrm{O}_{10}(\mathrm{OH})_{2}+5 \mathrm{MgCO}_{3}
$$

However, talc and magnesite relative volumes observed in fluid inclusions (Fig. 3a) suggest that sub-equal molar amounts of these two phases were produced during the reaction, given that the molecular weight of talc is about five times that of magnesite ( 379 vs. 84 ), for similar densities $\left(2.78\right.$ vs. $\left.3.01 \mathrm{~g} / \mathrm{cm}^{3}\right)$. Relative proportions of talc and magnesite can be greatly modified if $\mathrm{H}_{2} \mathrm{O}$ $\mathrm{CO}_{2}$ fluids contained $\mathrm{SiO}_{2}$ in solution:

$$
2 \mathrm{Mg}_{2} \mathrm{SiO}_{4}+\mathrm{H}_{2} \mathrm{O}+\mathrm{CO}_{2}+2 \mathrm{SiO}_{2}(\mathrm{aq})=\mathrm{Mg}_{3} \mathrm{Si}_{4} \mathrm{O}_{10}(\mathrm{OH})_{2}+\mathrm{MgCO}_{3}
$$




$$
4 \mathrm{MgSiO}_{3}+\mathrm{H}_{2} \mathrm{O}+\mathrm{CO}_{2}=\mathrm{Mg}_{3} \mathrm{Si}_{4} \mathrm{O}_{10}(\mathrm{OH})_{2}+\mathrm{MgCO}_{3}
$$

However, while magnesite represents a common phase in fluid inclusions, talc is more rare.

It is thus possible that a second reaction such as:

$$
\mathrm{MgSiO}_{3}+\mathrm{CO}_{2}=\mathrm{MgCO}_{3}+\mathrm{SiO}_{2}
$$

might have occurred between $\mathrm{H}_{2} \mathrm{O}-\mathrm{CO}_{2}$ fluids of variable $\mathrm{X}_{\mathrm{H} 2 \mathrm{O}}$ and surrounding orthopyroxene.

In contrast, fluid inclusions in clinopyroxene do not seem to contain or have contained $\mathrm{H}_{2} \mathrm{O}$.

Talc and magnesite are rare, and FT-IR absorption maps do not show significant water enrichments. This result is surprising, given that the capacity of clinopyroxene to store $\mathrm{H}_{2} \mathrm{O}$ greatly exceeds that of olivine at upper mantle pressures (Aubaud et al, 2004). Although we may have overlooked some processes, as the studied clinopyroxene is from hydrous peridotites where metasomatic amphibole or phlogopite are present, our preferred explanation for the analytical data is that reaction of the hydrous fluid occurred along microfractures at the infiltration stage, prior to inclusion formation. Hydration of clinopyroxene during microfracture healing is suggested by formation of tiny pargasite (or phlogopite) grains, occurring with $\mathrm{CO}_{2}$ fluid inclusions along the same microfracture (Fig. 4). In olivine and orthopyroxene, similar hydration reactions are inhibited, since they occur at lower temperatures below most mantle geotherms (see also section 5.2), and hydrous mantle fluids are trapped inside inclusions. Interestingly, Lamb et al. (1987) proposed a similar evolution to explain selective $\mathrm{CO}_{2}$ enrichments observed in fluid inclusions of some high-grade metamorphic rocks.

\subsection{Amounts of water in shallow-mantle fluids}

A critical question to petrological and geophysical studies is how much water was originally present in shallow-mantle fluids. This issue can be investigated by modeling the reactions between $\mathrm{H}_{2} \mathrm{O}-\mathrm{CO}_{2}$ fluid inclusions and surrounding magnesian orthopyroxene $(\mathrm{Mg} / \mathrm{Mg}+\mathrm{Fe}=0.9)$ 
in peridotites. For magnesian olivine, similar reactions cannot be modeled since they require $\mathrm{SiO}_{2}$ in the fluid (cf., reaction 2 in 5.1). Figure 7 shows $T-\mathrm{X}_{\mathrm{H} 2 \mathrm{O}}$ phase diagrams for the MFSHC model system at different pressures. The model reactions can be used to simulate the chemical re-equilibrations between aqueous-carbonic fluids with different $\mathrm{X}_{\mathrm{H} 2 \mathrm{O}}$ in inclusions and surrounding orthopyroxene. These diagrams show that the minimum $\mathrm{X}_{\mathrm{H} 2 \mathrm{O}}$ necessary to induce hydration reactions between fluid inclusions and surrounding minerals increases with increasing fluid pressure. If we consider the formation of talc inside a fluid inclusion in orthopyroxene, at 1 $\mathrm{GPa}$, the minimum $\mathrm{X}_{\mathrm{H} 2 \mathrm{O}}$ is 0.25 (see invariant point 1 in Fig. $7 \mathrm{~b}$ ), while at $0.5 \mathrm{GPa}$, it decreases to $\mathrm{X}_{\mathrm{H} 2 \mathrm{O}}=0.1$ (invariant point 1 in Fig. $7 \mathrm{c}$ ). The maximum $\mathrm{X}_{\mathrm{H} 2 \mathrm{O}}$ should not exceed 0.5 regardless of pressure, since ensuing reactions would consume equal amounts of $\mathrm{H}_{2} \mathrm{O}$ and $\mathrm{CO}_{2}$, whereas observed fluid inclusions have $\mathrm{CO}_{2}$-rich compositions. From figure 7, it is also evident that reactions between $\mathrm{H}_{2} \mathrm{O}-\mathrm{CO}_{2}$ fluid inclusions and the surrounding minerals cannot be a mantle process, as talc and/or magnesite only forms as temperatures decrease below about $700-600^{\circ} \mathrm{C}$ for variable pressures. We propose that eruption provides the conditions to induce reactions. In explosive eruptions, temperatures of xenoliths fall below $600^{\circ} \mathrm{C}$ over $5-10 \mathrm{sec}$. of ballistic transport through the air (Shaw, 2009). Even in slower-cooling lavas, xenoliths take only a few hours to reach the same temperatures.

A strong dependency on pressure for hydrous fluid inclusion evolution is illustrated in Figure 8. Consider a dense $\mathrm{CO}_{2}-\mathrm{H}_{2} \mathrm{O}$ fluid inclusion with $\mathrm{X}_{\mathrm{H} 2 \mathrm{O}}=0.3$ in orthopyroxene formed at $1.5 \mathrm{GPa}$ and $1000^{\circ} \mathrm{C}$ in a mantle peridotite. When this inclusion ascends rapidly and adiabatically in a xenolith within the host magma, it will effectively become overpressurized (path a in Fig. 8). If decrepitation does not occur, it arrives at the surface, and subsequent syn-, and post-eruptive decrease of temperature will cool the fluid in the inclusion along an isochore (path b in Fig. 8). At temperatures below approximately $700^{\circ} \mathrm{C}, \mathrm{CO}_{2}-\mathrm{H}_{2} \mathrm{O}$ fluid reaction with surrounding minerals promotes the formation of magnesite in inclusions, but not hydrous phases (i.e., reaction 4 in 5.1). As far as a fluid inclusion remains overpressurized during adiabatic ascent and cooling, 
hydrous phases cannot form. When the same fluid inclusion decrepitates during ascent, so that fluid density resets to a lower value corresponding, for example, to $P<1 \mathrm{GPa}$ (below point 1 in Fig. 8), syneruptive cooling along isochore (path c in Fig. 8) would make the $\mathrm{CO}_{2}-\mathrm{H}_{2} \mathrm{O}$ fluids in the inclusion to react to form talc + magnesite (reaction 3 in 5.1).

In summary, thermodynamic modeling suggests that up to 50 mole $\%$ water should have been present in fluid inclusions formed at mantle depths in order to drive the observed reactions in orthopyroxene. Petrogenetic grids also show that syneruptive cooling in host peridotite xenoliths promotes fluid reactions with surrounding minerals. Lower overpressures in the fluid inclusion require a lower minimum water amount in the fluid in order for hydration reactions to take place. It appears reasonable to conclude that hydration reactions associated with diffusive water loss reset fluid inclusions to the minimum concentration of $\mathrm{H}_{2} \mathrm{O}$ and produce a dehydration trend which may result in the "pure $\mathrm{CO}_{2}$ " inclusions often described in mantle minerals. It is noteworthy to recall that any geobarometric data derived from similar $\mathrm{CO}_{2}$-rich inclusions could result in underestimates, since $\mathrm{CO}_{2}$-rich fluids would have residual composition and density considerably lower than that of the original mantle fluids at the time of entrapment.

\subsection{Reevaluation of shallow-mantle fluid composition}

In the absence of pristine inclusions in mantle minerals, an accurate characterization of the chemistry of the aqueous fluid component is complicated. Even so, the identity of minerals precipitating inside fluid inclusions through reactions with surrounding minerals gives information on the nature of species in solution. Ubiquitous talc forming through fluid reaction with surrounding host phases indicates $\mathrm{Si}$ as a major solute component (cf., reactions 2 and 3 in 5.1). Additionally, relevant amounts of $\mathrm{Cl}, \mathrm{S}, \mathrm{Ca}, \mathrm{K}$, and $\mathrm{Na}$ are revealed by chlorides and gypsum precipitated in inclusions on cooling. Interestingly, $\mathrm{K}$ seems to be present in relatively higher amounts than Na. Sulfur has been identified either as hydrogen sulfide gas $\left(\mathrm{H}_{2} \mathrm{~S}\right)$, elemental sulfur $\left(\mathrm{S}_{8}\right)$, or as sulfate ions (hydrated form of $\left.\mathrm{SO}_{3}\right)$ (Table1) depending on the 
oxidation state of the fluid, and indeed sulfur appears to bear a major control over the oxidation state. The sulfate ions detected in some fluid inclusions are a real feature, since, eventual postentrapment fluid inclusion redox-reactions would tend to reduce sulfur (Grishina et al., 1992).

The model composition of saline multicomponent mantle fluids that emerges from the present study is in agreement with formation of Cl-rich hydrous metasomatic phases and with extreme LILE enrichments in the studied peridotites (cf., section 2). In addition, the applicability of new chemical data to natural mantle fluids is supported by studies on major element solubility at high $P$ and $T$. Experimental data up to $3 \mathrm{GPa}$ and $1300^{\circ} \mathrm{C}$ indicate alkalis as the most soluble species in aqueous fluids, followed by $\mathrm{Cl}, \mathrm{Si}$, and $\mathrm{Ca}$, while $\mathrm{Mg}$ and $\mathrm{Fe}$ are relatively less soluble (Brenan et al., 1995; Dvir et al., 2011; Eggler, 1987; Kawamoto et al., 2004; Manning, 2004; Nakamura and Kushiro, 1974; Newton and Manning, 2002; Stalder et al., 2001). For example, Nakamura and Kushiro (1974) estimated that 20 wt. \% silica is dissolved in $\mathrm{H}_{2} \mathrm{O}$ fluids coexisting with mantle enstatite at $1.5 \mathrm{GPa}$ and $1280^{\circ} \mathrm{C}$. The presence of $\mathrm{CO}_{2}$ in the fluid strongly depresses the solubility of silica, while the presence of chlorine has the opposite effect (cf., Newton and Manning, 2010).

Previous direct measurements indicated that $10-14 \mathrm{wt} \%$ solutes (in $\mathrm{NaCl}$ equivalent) are present in hydrous fluid inclusions from the Ethiopian plateau (see section 2). Measured solute concentrations are in agreement with $2-5 \mathrm{wt} \% \mathrm{Cl}$ (or 3.5-9 wt. \% in $\mathrm{NaCl}$ equivalent) predicted for mantle fluids (Burgess and Turner, 1995), and with 6-10 wt \% solutes measured in $\mathrm{H}_{2} \mathrm{O}$-rich subduction fluids (1-2 GPa; Manning, 2004). The total fluid solute content cannot have been extreme in order to trap homogeneous fluids in inclusions (Figs. 1 and 2). High-salinity aqueous fluids, having a large immiscibility solvus in the $\mathrm{CO}_{2}-\mathrm{H}_{2} \mathrm{O}-\mathrm{NaCl}$ system, would have been immiscible with $\mathrm{CO}_{2}$ at the considered mantle $P-T$ conditions (Touret, 1992; 2009). Phase separation (into $\mathrm{L}+\mathrm{V}$ ) would have formed distinct $\mathrm{CO}_{2}$-rich and saline-aqueous fluid inclusions in mantle minerals, which have not been observed. Based on these observations, the concentrated 
brines ( $\mathrm{NaCl} \geq 50 \mathrm{wt} \%$; Scambelluri et al., 1997) described in fluid inclusions of some peridotites from subduction settings are likely to reflect the evolution of multicomponent fluids towards increasing solute/ $\mathrm{H}_{2} \mathrm{O}$ ratios either by decompression-induced phase separation in the $\mathrm{CO}_{2}-\mathrm{H}_{2} \mathrm{O}$-salt fluid system, or by postentrapment inclusion "dehydration" trends.

\subsection{Origin of water and chlorine in shallow-mantle fluids}

Cl-bearing hydrous fluids may be common in subduction zones, generated by the breakdown of hydrous minerals (e.g., serpentine; Manning, 2004; Poli and Schmidt, 2002; Scambelluri et al., 2001; Sharp and Barnes, 2004). Thus, peridotites from mantle wedges are the best candidates to find hydrous fluid inclusions. In this respect, fluid inclusions in peridotites from Central Italy and Sardinia may testify to metasomatic fluids released during old subduction events. As noted by Peccerillo (2005), in Italy and the southern Tyrrhenian sea, Plio-Quaternary magma generation does not necessarily need to be coeval with subduction and mantle metasomatism; it may postdate these processes, and could be triggered by changes in thermal regimes in the upper mantle.

Our data raise the question of the origin of aqueo-carbonic fluids carrying significant amounts of $\mathrm{Cl}$ in the lithosphere within the context of intraplate and extensional mantle settings (e.g., Ethiopia, and Hawaii) (Le Roux et al., 2006; Michael and Schilling, 1989; Seaman et al., 2004; Stolper et al., 2004). In the east African lithosphere, evidence for mantle metasomatism driven by $\mathrm{Cl}$-bearing hydrous fluids is consistently reported from several xenolith localities and supposed to have occurred during the early stages of mantle upwelling. The Cl-pargasite bearing lithosphere under the Ethiopian plateau is considered to have been modally metasomatized by $\mathrm{CO}_{2}$-brine fluids, probably derived by degassing of deep carbonate rich melts during early stages of upwelling of the Afar mantle zone (Frezzotti et al., 2010). Additionally, Cl-rich pargasite in spinel lherzolites of Zabargad Island is interpreted to have formed just before the early rifting phase of the Red Sea (Agrinier et al., 1993). In a similar way, the growth of amphibole \pm Cl- 
apatite in spinel peridotites from Yemen has been proposed to have been induced by the influx of carbonatitic melts and hydrous fluids from the Afar plume during the Oligocene (Baker et al., 1998). At Hawaii, Iceland, and Azores, Cl-enrichment in the lithosphere is indicated by the high Cl/F ratios of melt inclusions in OIB (e.g., Dixon et al., 2008; Le Roux et al., 2006; Michael and Schilling, 1989; Seaman et al., 2004; Stolper et al., 2004).

There should be other water and $\mathrm{Cl}$-sources besides active subduction. Evidence for hydrous mantle fluids away from subduction zones has been obtained in cratonic areas by fluid inclusions in fibrous diamonds, where fluids consist of three main components: a carbonate melt, a silicate melt, and a hydro-saline fluid (e.g., Izraeli et al., 2001; Klein-BenDavid et al., 2004; 2007; Kopylova et al., 2010; Navon et al., 1988). The hydrous fluid component is enriched in $\mathrm{SiO}_{2}$, $\mathrm{Al}_{2} \mathrm{O}_{3}$, halides, and alkalis (mainly $\mathrm{K}$ ), similar to shallower hydrous fluids reported by this study. The total solute content is, however, considerably higher in diamond fluids (e.g., $\mathrm{Cl}$ up to ca. 35 wt. \%), possibly reflecting the increase of elements solubility at greater $P$ and $T(P \geq 4-5 \mathrm{GPa}$; e.g., supercritical fluid phases; Bureau and Keppler, 1999; Kawamoto et al., 2004; Kessel et al., 2005; Manning, 2004). In diamonds, continuous compositional variations of fluid inclusions are observed, suggesting that all components might be genetically related, most likely evolved from a "primitive" carbonate-rich melt (cf., Klein-BenDavid et al., 2004, and references therein). Recent experimental evidence shows that immiscibility processes in this silicate-carbonate- $\mathrm{H}_{2} \mathrm{O}$ system facilitate the chlorine enrichment of the carbonate melt or of the aqueous fluid, not only at high pressures in the diamond stability field, but also at lithospheric pressures (Litasov and Ohtani, 2009; Litasov et al., 2011; Safonov, 2011).

It is conceivable to suppose that Cl-bearing hydrous shallow mantle fluids might have been formed through hydro-saline carbonate melts. As mentioned above, the model composition of hydrous shallow mantle fluids in spinel peridotites is similar to that of the aqueous fluid component trapped deeper, in diamonds. Further comparisons are difficult because of the limited data. Fluxes of $\mathrm{CO}_{2}-\mathrm{H}_{2} \mathrm{O}$ and $\mathrm{Cl}$ in the lithosphere could have been generated by degassing of 
upwelling carbonate-rich melts at pressures below the carbonate-stability field (2-2.5 GPa; Dobson et al., 1996; Hammouda and Laporte, 2000). Since fluid data from mantle rocks in intraplate and extensional tectonic settings are limited, it is not known whether carbonate-melt degassing may be the main source of lithospheric hydrous fluids, or some other mechanisms, such as silicate melt - fluid immiscibility, have to be invoked. In any case, the deep association of $\mathrm{CO}_{2}, \mathrm{H}_{2} \mathrm{O}$, carbonates, and diamonds preserved in fluid inclusions of Hawaiian garnet pyroxenites (Frezzotti an Peccerillo, 2007) was interpreted to have caught this process in the act.

\section{Conclusions}

The methodology presented in this paper shows that water is an elusive component in fluid inclusions in many hydrous and anhydrous upper mantle peridotites (i.e., Hawaii, Ethiopia, Canary Islands, and the western Mediterranean region). In shallow-mantle rocks, "pure $\mathrm{CO}_{2}$ " inclusions observed optically should be considered to contain less than 20 mole $\%$ of $\mathrm{H}_{2} \mathrm{O}$, in absence of spectroscopic analysis. Raman identification of $\mathrm{H}_{2} \mathrm{O}$, as $\mathrm{OH}^{-}$, bound in hydrous silicates lining fluid inclusions suggests that hydrous fluid/host mineral chemical reactions represent a common postentrapment process, leading to fluid inclusion dehydration. FT-IR analysis of the distribution of water enrichment in mantle minerals suggests further dehydration through decrepitation, stretching, and $\mathrm{H}_{2} \mathrm{O}$ diffusion.

Although shallow mantle fluids are generally dominated by $\mathrm{CO}_{2}$, constraints from thermodynamic modeling in the MFSHC system suggest that up to 50 mole $\% \mathrm{H}_{2} \mathrm{O}$ could be present. Water activity $\left(\mathrm{a}_{\mathrm{H} 2 \mathrm{O}}\right)$ is expected to be low (probably $\left.<0.4\right)$, in agreement with the anhydrous nature of many peridotite xenoliths. However, the existence of a hydrous fluid component will influence the physical and chemical evolution of the shallow mantle. Presence of $\mathrm{H}_{2} \mathrm{O}$ and solutes makes migration of fluids more effective (Mibe et al., 1998, 1999; 2002; Watson and Brenan. 1987). Moreover, the solute content in such hydrous fluids will affect 
transport and partitioning of elements inducing metasomatism in mantle rocks (Ayers, 1998; Keppler, 1996; Kessel at al., 2005; Konrad-Schmolke et al., 2011).

In extending present results to a broad statement about the composition of shallow-mantle fluid inclusions, we propose that multicomponent fluids are widespread in the shallow mantle, not only in subduction-zone settings, but also in extensional or intraplate settings. However, a stronger validation requires further spectroscopic (re)investigation of fluid inclusions in mantle peridotites.

\section{Acknowledgments}

We acknowledge T. Anderesen, J. Touret and an anonymous reviewer for most constructive reviews. We also thank B. Marty for his stimulating comments which greatly improved the manuscript. We are grateful to the National Museum of Natural History (Washington D.C.) for providing the Salt Lake Crater peridotite samples. We thank M. Placidi for the fine technical assistance on Raman spectroscopy, A. Perucchi for help in FT-IR maps treatment, as well as R. Bonelli and G. Giorgetti for help with SEM analyses. This study was supported by the Italian PRIN/2008BYTF98. 


\section{References}

Agrinier, P., Mével, C., Bosch, D., Javoy, M., 1993. Metasomatic hydrous fluids in amphibole peridotites from Zabargad Island (Red Sea). Earth Planet. Sci. Lett. 120, 187-205.

Andersen, T., Neumann, E.R., 2001. Fluid inclusions in mantle xenoliths. Lithos 55, 301-320.

Andersen T., O'Reilly, S.Y., Griffin W.L., 1984. The trapped fluid phase in upper mantle xenoliths from Victoria. Implications for mantle metasomatism. Contrib. Mineral. Petrol. 88, 72-85.

Asimow, P.D., Langmuir, C.H., 2003. The importance of water to oceanic mantle melting regimes. Nature 421, 815-820.

Aubaud C., Hauri, E.H., Hirschmann, M.M., 2004. Hydrogen partition coefficients between nominally anhydrous minerals and basaltic melts. Geophys. Res. Lett. 31, L20611, doi:10.1029/2004GL021341.

Ayers, J., 1998. Trace element modeling of aqueous fluid-peridotite interaction in the mantle wedge of subduction zones. Contrib. Mineral. Petrol. 132, 390-404. Bailey, D.K., 1982. Mantle metasomatism--Continuing chemical change within the Earth. Nature 296, 525-530.

Bailey, D.K., 1982. Mantle metasomatism: Continuing chemical change within the earth. Nature 296,525-530.

Baker, J.A., Chazot, C., Menzies, M., Thirwall, M., 1998. Metasomatism of the shallow mantle beneath Yemen by the Afar plume: implications for plumes, flood volcanism, and intraplate volcanism. Geology 26, 431-434.

Bakker, R.J., Jansen, J.B.H., 1991. Experimental post-entrapment water loss from synthetic $\mathrm{CO}_{2-}$ $\mathrm{H}_{2} \mathrm{O}$ inclusions in natural quartz. Geochim. Cosmochim. Acta 55, 2215-2230.

Bell, D.R., Ihinger, P.D., Rossman, G.R., 1995. Quantitative analysis of trace OH in garnet and pyroxenes. Am. Mineral. 80, 465-474.

Bell, D.R., Rossman, G.R., Maldener, J., Endisch, D., Rauch, F., 2003. Hydroxide in olivine: a quantitative determination of the absolute amount and calibration of the IR spectrum. J. Geophys. Res. 108, 2105. doi:10.1029/2001JB000679.

Bolfan-Casanova, N., Keppler, H., Rubie, D.C., 2000. Water partitioning between nominally anhydrous minerals in the $\mathrm{MgO}-\mathrm{SiO}_{2}-\mathrm{H}_{2} \mathrm{O}$ system up to $24 \mathrm{GPa}$ : implications for the distribution of water in the Earth's mantle. Earth Planet. Sci. Lett. 182, 209-221.

Brenan, J.M., Shaw, H.F., Reyrson, F.J., Phinney, D.L., 1995. Mineral aqueous fluid partitioning of trace elements at $900^{\circ} \mathrm{C}$ and $2.0 \mathrm{GPa}$ : constraints on the trace element chemistry of mantle and deep crustal fluids, Geochim. Cosmochim. Acta 59, 3331-3350.

Bureau, H., Keppler, H., 1999. Complete miscibility between silicate melts and hydrous fluids in the upper mantle: experimental evidence and geochemical implications. Earth Planet. Sci. Lett. 165, 187-196.

Burgess, R., Turner, G., 1995. Halogen geochemistry of mantle fluids in diamonds, in: Farley, K.A. (Ed.), Volatiles in the Earth and Solar system. Proc. AIP Conf. 341, 91-98.

Clague, D.A., Frey, F.A., 1982. Petrology and trace element chemistry of the Honolulu volcanics, Oahu: implication for the oceanic mantle below Hawaii, J. Petrol. 23, 447-504.

Connolly, J.A.D.,1990. Multivariable phase diagrams: an algorithm based on generalized thermodynamics. Am. J. Sci. 290, 666-718. 
Connolly, J.A.D., 1995. Phase-diagram methods for graphitic rocks and application to the system C-O-H-FeO-TiO $2-\mathrm{SiO}_{2}$. Contrib. Mineral. Petrol. 119, 94-116.

Conticelli, S., 1998. The effect of crustal contamination on ultrapotassic magmas with lamproitic affinity: mineralogical, geochemical and isotope data from the Torre Alfina lavas and xenoliths, Central Italy. Chem. Geol. 149, 51-81.

Conticelli, S., Peccerillo, A., 1990. Petrological significance of high-pressure ultramafic xenoliths from ultrapotassic rocks of Central Italy. Lithos 24, 305 - 322.

Dasgupta, R., Hirschmann, M.M., 2006. Melting in the Earth's deep upper mantle caused by carbon dioxide. Nature 440, 659-662.

Demouchy, S., Jacobsen, S.D., Gaillard, F., Stern, C.R., 2006. Rapid magma ascent recorded by water diffusion profiles in mantle olivine. Geology 34, 429-432.

Dixon, J.D.A., Clague, B., Cousens, M.L., Monsalve, Uhl, J., 2008, Carbonatite and silicate melt metasomatism of the mantle surrounding the Hawaiian plume: Evidence from volatiles, trace elements, and radiogenic isotopes in rejuvenated-stage lavas from Niihau, Hawaii, Geochem. Geophys. Geosyst. 9, Q09005, doi:10.1029/2008GC002076.

Dixon, J.E., Dixon, T.H., Bell, D.R., Malservisi, R., 2004. Lateral variation in upper mantle viscosity: role of water. Earth Planet. Sci. Lett. 222, 451-67

Dixon, J.E., Leist, L., Langmuir, C., Schilling, J.G., 2002. Recycled dehydratrated lithosphere observed in plume-influenced mid-ocean-ridge basalt. Nature 420, 385-389.

Dobson, D.P., Jones, A.P., Rabe, R., Sekine, T., Kurita, K., Taniguchi, T., Kondo, T., Kato, T., Shimomura, O. and Urakawa, S., 1996. In-situ measurement of viscosity and density of carbonate melts at high pressure. Earth Planet. Sci. Lett. 143, 207-215.

Dvir, O, Pettke, T., Fumagalli, P., Kessel, R., 2011. Fluids in the peridotite-water system up to 6 GPa and 800: new experimental constrains on dehydration reactions. Contrib. Mineral. Petrol. 161, 829-844.

Eggler, D.H., 1987. Solubility of major and trace elements in mantle metasomatic fluids: experimental constraints. In: Menzies MA, Hawkesworth CJ (eds) Mantle metasomatism. Academic Press, New York, 21-42

Ferrando, S., Frezzotti, M.L., Neumann, E.R., De Astis, G., Peccerillo, A., Dereje, A., Gezahegn, Y., Teklewold, A. 2008. Composition and thermal structure of the lithosphere beneath the Ethiopian plateau: evidence from mantle xenoliths in basanites, Injibara, Lake Tana Province. Mineral. Petrol. 93, 47-78.

Ferrando, S., Frezzotti, M.L., Petrelli, M., Compagnoni, R., 2009. Metasomatism of continental crust during subduction: the UHP whiteschists from the Southern Dora-Maira Massif (Italian Western Alps), J. Metamorphic Geol. 27, 739 - 756.

French, B.M., 1966. Some geological implications of equilibrium between graphite and a C-H-O gas phase at high temperatures and pressures. Rev. Geophys. 4, 223-254.

Frezzotti, M.L., Peccerillo, A., 2007. Diamond-bearing COHS fluids in the mantle beneath Hawaii. Earth Planet. Sci. Lett. 262, 273-283.

Frezzotti, M.L., Burke, E.A.J., De Vivo, B., Stefanini, B., Villa, I.M., 1992. Mantle fluids in pyroxenite nodules from Salt Lake Crater (Oahu, Hawaii). Eur. J. Mineral. 4, 1137-1153.

Frezzotti, M.L., Andersen, T., Neumann, E.R, Simonsen, S.L., 2002a. Carbonatite melt- $\mathrm{CO}_{2}$ fluid inclusions in mantle xenoliths from Tenerife, Canary Islands: a story of trapping, immiscibility and fluid-rock interaction in the upper mantle. Lithos 64,77-96. 
Frezzotti, M.L., Touret, J.L.R., Neumann, E.R., 2002b. Ephemeral carbonate melts in the upper mantle: carbonate-silicate immiscibility in microveins and inclusions within spinel peridotite xenoliths, La Gomera, Canary Islands. Eur. J. Mineral. 14, 891-904.

Frezzotti, M.L., Peccerillo, A., Panza, G., 2009. Carbonate metasomatism and CO2 lithosphereastenosphere degassing beneath the Western Mediterranean: an integrated model arising from petrological and geophysical data. Chem. Geol. 262, 108-120.

Frezzotti, M.L., Ferrando, S., Peccerillo, A., Tecce, F., Petrelli, M., 2010. Chlorine-rich metasomatic $\mathrm{H}_{2} \mathrm{O}-\mathrm{CO}_{2}$ fluids in amphibole-bearing peridotites from Injibara (Lake Tana region, Ethiopian plateau): nature and evolution of volatiles in the mantle of a region of continental flood basalts. Geochim. Cosmochim. Acta, 74, 3023 -3039.

Frezzotti, M.L., Tecce, F., Casagli, A., 2012. Raman spectroscopy for fluid inclusion analysis. J. Geochem. Expl. 112, 1-20.

Green, D.H., Falloon, T.J., 1998. Pyrolite: a Ringwood concept and its current expression. in Jackson, J. (Ed.), The Earth's Mantle. Cambridge Univ. Press, New York, pp. 311-378.

Grishina, S., Dubessy, J., Kontorovitch, A., Pironon, J., 1992. Inclusions in salt beds resulting from thermal metamorphism by dolerite sills (eastern Siberia, Russia). Eur. J. Mineral. 4, 1187-1202

Hammouda, T., Laporte, D. 2000. Ultrafast mantle impregnation by carbonatite melts. Geology 28, 283-285.

Hidas, K., Guzmics, T., Szabó, C., Kovács, I., Bodnar, R.J., Zajacz, Z., Nédli, Z., Vaccari, L., Perucchi, A., 2010. Coexisting silicate melt inclusions and $\mathrm{H}_{2} \mathrm{O}$-bearing, $\mathrm{CO}_{2}$-rich fluid inclusions in mantle peridotite xenoliths from the Carpathian-Pannonian region (central Hungary). Chem. Geol. 274, 1-18.

Hirth, G., Kohlstedt, D.L., 2003. Rheology of the upper mantle and the mantle wedge: a view from the experimentalists, in: Eiler J. (Ed.), Inside the Subduction Factory. AGU, Washington, D.C., pp. 83-105.

Holland, T.J.B., Powell, R., 2011. An improved and extended internally consistent thermodynamic dataset for phases of petrological interest, involving a new equation of state for solids. J. metamorphic Geol. 29, 333-383.

Hollister, L.S., 1990. Enrichment of $\mathrm{CO}_{2}$ in fluid inclusions in quartz by removal of $\mathrm{H}_{2} \mathrm{O}$ during crystal-plastic deformation. J. Struct. Geol. 12, 895-901.

Huizenga, J.M., 2001. Thermodynamic modeling of C-O-H fluids. Lithos, 55. 101-114.

Huizenga, J.M., 2005. C-O-H, an Excel spreadsheet for composition calculations in the C-O-H fluid system. Comput. Geosci. 31, 797-800.

Jackson, E.D., Wright, T.L., 1970. Xenoliths in the Honolulu volcanic series, Hawaii, J. Petrol. 11, 405-430.

Izraeli, E.S., Harris, J.W., Navon, O., 2001. Brine inclusions in diamonds: a new upper mantle fluid. Earth Planet. Sci. Lett. 187, 323-332.

Katayama, I., Karato S.I., 2008. Low-temperature, high-stress deformation of olivine under water-saturated conditions. Phys. Earth Planet. Int. 168, 125-133.

Katz, R.F., Spiegelman, M., Langmuir, C.H., 2003. A new parameterisation of hydrous mantle melting. Geochem. Geophys. Geosyst. 4, 9, 1073.

Kawamoto, T., Matsukage, K.N., Mibe, K., Isshiki, M., Nishimura, K., Ishimatsu, N., Ono, S., 2004. $\mathrm{Mg} / \mathrm{Si}$ ratios of aqueous fl uids coexisting with forsterite and enstatite based on the phase relations in the $\mathrm{Mg}_{2} \mathrm{SiO}_{4}-\mathrm{SiO}_{2}-\mathrm{H}_{2} \mathrm{O}$ system. Am. Mineral. 89,1433-1437. 
Keppler H., 1996. Constraints from partitioning experiments on the composition of subductionzone fluids, Nature 380, 237-240.Keshav, S., Sen, G., 2001. Majoritic garnets in Hawaiian xenoliths: preliminary results. Geophys. Res. Lett. 28, 3509-3512.

Keshav, S., Sen, G., 2003. A rare composite xenolith from Salt Lake Crater, Oahu: high-pressure fractionation and implications for kimberlitic melts in the Hawaiian mantle. Contrib. Mineral. Petrol. 144, 548-558.

Keshav, S., Sen, G., Presnall, D.C., 2007. Garnet-bearing xenoliths from Salt Lake Crater, Oahu, Hawaii: High-pressure fractional crystallization in the oceanic mantle. J. Petrol. 48, 16811724.

Kessel R., Schmidt M.W., Ulmer P., Pettke T., 2005. Trace element signature of subductionzone fluids, melts and supercritical liquids at 120-180 km depth, Nature, 437, 724-727.

Khisina, N.R., Wirth, R., Andrut, M., Ukhanov, AV., 2001. Extrinsic and intrinsic mode of hydrogen occurrence in natural olivines: FTIR and TEM investigation. Phys. Chem. Miner. 28, 291-301.

Klein-BenDavid, O., Izraeli, E.S., Hauri, E., Navon O., 2004. Mantle fluid evolution - a tale of one diamond. Lithos 77, 243-253.

Klein-BenDavid, O., Izraeli, E. S., Hauri, E., Navon, O., 2007. Fluid inclusions in diamonds from the Diavik mine, Canada and the evolution of diamond-forming fluids. Geochim. Cosmochim. Acta 71, 723-744.

Konrad-Schmolke, M., Zack, T., Brien, P.J., 2011. Fluid migration above a subducted slab: thermodynamic and trace element modeling of fluid-rock interaction in partially overprinted eclogite-facies rocks (Sesia Zone, Western Alps). Earth Planet. Sci. Lett. 311, 287-298.

Kopylova, M., Navon, O., Dubrovinsky, L., Khachatryan, G., 2010. Carbonatitic mineralogy of natural diamond-forming fluids. Earth Planet. Sci. Lett. 291, 126-137.

Lamb, W.M., Valley J.W., Brown P.E., 1987. Post-metamorphic $\mathrm{CO}_{2}$-rich fluid inclusions in granulites. Contrib. Mineral. Petrol. 96, 485-495.

Lassiter, J.C., Hauri, E.H., Reiners, P., Garcia, M.O., 2000. Generation of Hawaiian posterosional lavas by melting of a mixed lherzolite/pyroxenite source. Earth Planet. Sci. Lett. 178, 269-284.

Le Roux, P.J., Shirey, S.B., Hauri, E.H., Perfit, M.R., Bender, J.F., 2006. The effects of variable sources, processes and contaminants on the composition of northern EPR MORB $\left(8-10^{\circ} \mathrm{N}\right.$ \& $\left.12-14^{\circ} \mathrm{N}\right)$ : evidence from volatiles $\left(\mathrm{H}_{2} \mathrm{O}, \mathrm{CO}_{2}, \mathrm{~S}\right)$ and halogens $(\mathrm{F}, \mathrm{Cl})$. Earth Planet. Sci. Lett. 251, 209-231.

Litasov, K.D., Othani, E., 2009. Phase relations in the peridotite-carbonate-chloride system at 7.0-16.5 GPa and the role of chlorides in the origin of kimberlite and diamond. Chem. Geol. 262, 29-41.

Litasov, K.D., Shatskij, A.F., Pokhilenko, N.P., 2011. Phase relations and melting in the systems of peritotie-H2O-CO2 and eclogite-H2O-CO2 at pressures up to $27 \mathrm{GPa}$. Doklady Earth Sci. 437, 669-674.

Lustrino, M., Melluso, L., Morra, V., 2000. The role of lower continental crust and lithospheric mantle in the genesis of Plio-Pleistocene volcanic rocks from Sardinia (Italy). Earth Planet. Sci. Lett. 180, 259-270.

Lustrino, M., Brotzu, P., Lonis, R., Melluso, L., Morra, V., 2004. European subcontinental mantle as revealed by Neogene volcanic rocks and mantle xenoliths of Sardinia. 32nd Int. Geol. Congr., Post-Congress Guide P69, p. 42. 
Luth, R.W., 2003. Mantle volatiles - distribution and consequences, in: Carlson, R. (Ed.) The Mantle and Core, Volume 2, Holland, H.D., Turekian, K.K. (Eds.) Treatise on Geochemistry. Elsevier-Pergamon, Oxford, pp. 319-361.

Mackwell, S.J., Kohlstedt, D.L., 1990. Diffusion of hydrogen in olivine: implications for water in the mantle, J. Geophys. Res. 95, 5079-5088.

Manning, C.E., 2004. The chemistry of subduction-zone fluids. Earth Planet. Sci. Lett. 223, 116.

Marty, B., Tolstikhin, I.N., 1998. $\mathrm{CO}_{2}$ fluxes from mid-ocean ridges, arcs and plumes, Chemical Geology, 145, 233-248.

Marty, B., Zimmermann L., 1999. Volatiles (He, C, N, Ar) in midocean ridge basalts: Assessment of shallow-level fractionation and characterization of source composition, Geochim. Cosmochim. Acta, 63, 3619-3633.

McInnes, B.I.A., Gregoire, M., Binns, R.A., Herzig, P.M., Hannington, M.D., 2001. Hydrous metasomatism of oceanic sub-arc mantle, Lihir, Papua New Guinea; petrology and geochemistry of fluid-metasomatised mantle wedge xenoliths. Earth Planet. Sci. Lett. 188, $169-183$

McMillan, P.F., Dubessy, J., Hemley, R., 1996. Raman Microscopy. Applications in Earth, planetary and environmental sciences, in: Turrell, G., Corset, G. (Eds.), Academic Press, pp. 289-351.

Mibe, K., Fujii, T., Yasuda, A., 1998. Connectivity of aqueous fluid in the Earth's upper mantle. Geophys. Res. Lett. 25, 1233-1236.

Mibe, K., Fujii, T., Yasuda, A., 1999. Control of the location of the volcanic front by aqueous fluid connectivity in the mantle wedge. Nature 401, 259-262.

Mibe, K., Fujii, T., Yasuda, A., 2002. Composition of aqueous fluid coexisting with mantle minerals at high pressure and its bearing on the differentiation of the Earth's mantle, Geochim. Cosmochim. Acta 66, 2273-2285.

Michael, P.J., Schilling J.-G., 1989. Chlorine in mid-ocean ridge magmas: evidence for assimilation of seawater-influenced components. Geochim. Cosmochim. Acta 53, 31313143.

Murck, B.W., Burruss, R.C., Hollister, L.S., 1978. Phase equilibria in fluid inclusions in ultrarnafic xenoliths. Amer. Mineral. 63, 40-46.

Nakamura, Y., Kushiro I., 1974. Composition of the gas phase in $\mathrm{Mg}_{2} \mathrm{SiO}_{4}-\mathrm{SiO}_{2}-\mathrm{H}_{2} \mathrm{O}$ at $15 \mathrm{kbar}$, in: Year Book Carnegie Inst. Wash. 73, pp. 255-258.

Navon, O., Hutcheon, I.D., Rossman, G.R., Wasserburg G.J., 1988. Mantle-derived fluids in diamond micro-inclusions. Nature 335, 784-789.

Newton, R.C., Manning, C.E., 2002. Solubility of enstatite- forsterite in $\mathrm{H}_{2} \mathrm{O}$ at deep crust/upper mantle conditions: 4 to $15 \mathrm{kbar}$ and 700 to $900^{\circ} \mathrm{C}$. Geochim. Cosmochim. Acta 66, 4165 4176.

Newton, R.C., Manning, C.E., 2010. Role of saline fluids in deep-crustal and upper-mantle metasomatism: insight from experimental studies. Geofluids 10, 58-72.

Ohmoto, H., Kerrick, D., 1977. Devolatilization equilibria in graphitic systems. Am. J. Sci., 277 1013-1044.

Oppenheimer C., Moretti, R., Kyle, P.R., Eschenbacher, A., Lowenstern, J.B., Hervig, R.L., Dunbar, N.W., 2011. Mantle to surface degassing of alkalic magmas at Erebus volcano, Antarctica. Earth Planet. Sci. Lett. 306, 261-271. 
O'Reilly, S.Y., Griffin, W.L., 2000. Apatite in the mantle: implications for metasomatic processes and high heat production in Phanerozoic mantle. Lithos 53, 217-232.

Pasteris, J.D., 1987. Fluid inclusions in mantle xenoliths, in: Nixon, P.H. (Ed.) Mantle Xenoliths. Wiley, pp. 691-708.

Pasteris, J.D., Wanamaker, B .J., 1988. Laser Raman microprobe analysis of experimentally reequilibrated fluid inclusions in olivine: Some implications for mantle fluids. Am. Mineral. 13, 1074-1 088.

Paterson, M., 1982. The determination of hydroxyl by infrared absorption in quartz, silicate glasses and similar materials. Bull. Mineral. 105, 20-29.

Patiño Douce, A.E., Roden, M.F., Chaumba, J., Fleisher, C., Yogodzinski, G., 2011. Compositional variability of terrestrial mantle apatites, thermodynamic modeling of apatite volatile contents, and the halogen and water budgets of planetary mantles. Lithos 14-31.

Philippot, P., Selverstone, J., 1991. Trace-element-rich brines in eclogitic veins: implications for fluid composition and transport during subduction. Contrib. Mineral. Petrol. 106, 417-430.

Peccerillo, A., 2005. Plio-Quaternary volcanism in Italy. Petrology, geochemistry, geodynamics. Springer, Heidelberg. 365 pp.

Pera, E., Mainprice, D., Burlini, L., 2003. Anisotropic seismic properties of the upper mantle beneath the Torre Alfina area (northern Apennines, central Italy), Tectonophysics 370, 11 30 .

00175-6.

Poli, S., Schimidt, M.W., 2002. Petrology of subducted slabs. Ann. Rev. Earth Planet. Sci., 30, 207-235.

Roedder, E., 1965. Liquid $\mathrm{CO}_{2}$ inclusions in olivine-bearing nodules and phenocrysts from basalts. Amer. Mineral. 50, 1746-1782.

Roedder, E., 1972. Composition of fluid inclusions, in: Fleischer, M., (Ed.) Data of Geochemistry, 6th edition, U.S. Geological Survey Professional Paper 440JJ.

Roedder, E., 1984. Fluid Inclusions. Mineral. Soc. America. Rev. Mineral. 12.

Romer, R.L., Franz, L., Wirth, R., 2006. Chemical and isotopic effects of retrogression in metamorphic fluid inclusions. Contrib. Mineral. Petrol. 151, 174-186.

Safonov, O.G., 2011. Interaction of model peridotite with $\left(\mathrm{Ca}, \mathrm{Na}_{2}\right) \mathrm{CO}_{3}-\mathrm{KCl}$ melts and $\mathrm{H}_{2} \mathrm{O}-$ $\mathrm{KCl}$ fluids at 1.0-2.5 GPa. Vestnik Otdelenia nauk o Zemle RAN, 3, NZ6086, doi:10.2205/2011NZ000216.

Scambelluri, M., Piccardo, G.B., Philippot, P., Robbiano, A. and Negretti, L., 1997. High salinity fluid inclusions formed from recycled seawater in deeply subducted alpine serpentinite. Earth Planet. Sci. Lett. 148, 485-500.

Scambelluri, M., Bottazzi, P., Trommmmsdoff, V., Vannucci, R., Hermamann, J., GòmezPugnaire, M.T., Lòpez-Sànchez Vizcaino V., 2001. Incompatible element-rich fluids released by antigorite breakdown in deeply subducted mantle. Earth Planet. Sci. Lett., 192, 457-470.

Seaman, C., Sherman, S.B., Garcia, M.O., Baker, M.B., Balta, B. Stolper, E., 2004. Volatiles in glasses from the HSDP2 drill core. Geochem. Geophys. Geosyst. 5, Q09G16. doi:10.1029/2003GC000596.

Sen, G., 1988. Petrogenesis of spinel lherzolite and pyroxenite suite xenoliths from the Koolau shield, Oahu, Hawaii: implications for petrology of the post-eruptive lithosphere beneath Oahu, Contrib. Mineral. Petrol. 100, 61-91. 
Sharp, Z.D., Barnes, J.D., 2004. Water-soluble chlorides in massive seafloor serpentinites: a source of chloride in subduction zones. Earth Planet. Sci. Lett. 226, 243-254.

Shaw, C., 2009. Caught in the act - The first few hours of xenolith assimilation preserved in lavas of the Rockeskyllerkopf volcano, West Eifel, Germany. Lithos 112, 511-523.

Shi, P.F., Saxena, S.K., 1992. Thermodynamic modeling of the C-H-O-S fluid system. Am. Mineral. 77, 1038-1049.

Smith, J.V., Delaney, J.S., Hervig, R.L., Dawson, J.B., 1981. F and Cl in the upper mantle: geochemical implication, Lithos 14, 133-147.

Stalder R., Ulmer, P., Thompson, A.B., and Gunther, D., 2001. High pressure fluids in the system $\mathrm{MgO}-\mathrm{SiO}_{2}-\mathrm{H}_{2} \mathrm{O}$ under upper mantle conditions. Contrib. Mineral. Petrol. 140, 607618.

Sterner, S.M., Bodnar, R.J., 1989. Synthetic fluid inclusions. VII. Re-equilibration of fluid inclusions in quartz during laboratory-simulated metamorphic burial and uplift. J. Metamorphic Geol. 7, 243-260.

Stolper, E., Sherman, S., Garcia, M.O., Baker, M.B., Seaman, C., 2004. Glass in the submarine section of the HSDP2 drill core, Hilo, Hawaii. Geochem. Geophys. Geosyst. 5, doi: 10.1029/2003GC000553.

Thompson, A.B., 1992. Water in the Earth's upper mantle. Nature 358, 295-302.

Touret, J.L.R., 1981. Fluids in metamorphic rocks. Chap. 8, in: Short Course in Fluid Inclusions: Application to Petrology. Miner. Assoc. Canada, Calgary, 6, pp. 182-208.

Touret, J.L.R., 1992. $\mathrm{CO}_{2}$ transfer between the Upper Mantle and the atmosphere: temporary storage in the lower continental crust. Terra Nova 4, 87-98.

Touret, J.L.R., 2001. Fluids in metamorphic rocks. Lithos 55, 1-25.

Touret J.L.R., 2009. Mantle to lower-crust fluid/melt transfer through granulite metamorphism. Russian Geol. Geophys. 50, 1052-1062.

Trial, A.F., Rudnick, R.L., Ashwal, L.D., Henry, D.J., Bergman, S.C., 1984. Fluid inclusions in mantle xenoliths from Ichinomegata, Japan: Evidence for subducted $\mathrm{H}_{2} \mathrm{O}$. EOS Trans. Amer. Geophys. Union 65, 306.

Viti, C., Frezzotti, M.L., 2000. Re-equilibration of glass and $\mathrm{CO}_{2}$ inclusions in xenolith olivine: a TEM study. Am. Mineral. 85, 1390-1396.

Viti, C., Frezzotti, M.L., 2001. Transmission electron microscopy applied to fluid inclusion investigations. Lithos 55, 125 - 138.

Wallace, P.J., 2003. From mantle to atmosphere: magma degassing, explosive eruptions, and volcanic volatile budgets. Developments in Volcanology, Volume 5, pp 105-127.

Watson, E.B., Brenan, J.M., 1987. Fluids in the lithosphere, 1. Experimentally determined wettening characteristics of $\mathrm{CO}_{2}-\mathrm{H}_{2} \mathrm{O}$ fluids and their implications for fluid transport, hostrock physical properties, and fluid inclusion formation. Earth Planet. Sci. Lett. 85, 497-515.

Wirth, R, Rocholl, A., 2003. Nanocrystalline diamond from the Earth's mantle underneath Hawaii. Earth Planet. Sci. Lett. 211, 357-369.

Wyllie, P.J., Ryabchikov, I.D., 2000. Volatile components, magmas, and critical fluids in upwelling mantle. J. Petrol. 41, 1195-1206.

Zhang, C., Duan, Z., 2009. A model for C-O-H fluid in the Earth's mantle. Geochim. Cosmochim. Acta 73, 2089-2102.

Zhang, C., Duan, Z., 2010. GFluid: An Excel spreadsheet for investigating C-O-H fluid composition under high temperatures and pressures. Comp. Geosc. 36, 569-572. 


\section{Captions to Figures}

Fig. 1 - Raman detection of optically hidden liquid water in fluid inclusions. a) Trail of fluid inclusions in orthopyroxene. White asterisks indicate those fluid inclusions where liquid $\mathrm{H}_{2} \mathrm{O}$ was detected by Raman spectroscopy. b) Raman spectrum of liquid $\mathrm{H}_{2} \mathrm{O}$ rimming $\mathrm{CO}_{2}$ in a fluid inclusion in Fig. 2a.

Fig. 2 - Different extents of fluid inclusion-host reactions as detected by Raman microspectroscopy. Inclusions show textural evidence for an increasing reaction degree with the enclosing mineral going from microphotographs a-b, to c and d. a) Decrepitated high-density (monophase) $\mathrm{CO}_{2}$ fluid inclusion containing magnesite (Mgs) in orthopyroxene. b) Magnesite (Mgs) and talc (Tlc) in apparently preserved high density (monophase) $\mathrm{CO}_{2}$ fluid inclusions distributed along a trail in olivine. c) Decrepitated and reacted fluid inclusion in olivine. Inclusion contains two phase (liquid + vapor) $\mathrm{CO}_{2}, \mathrm{Mgs}$, and Tlc. d) Decrepitated and reacted fluid inclusion in olivine. The inclusion is filled by aggregates of Tlc and Mgs, with no visible fluid left. e) Raman modes of magnesite inside fluid inclusions. Unlabelled peaks refer to enclosing olivine. f) $\mathrm{OH}^{-}$Raman modes of talc recorded inside fluid inclusions.

Fig. 3 - EDS-EDAX and Raman analyses in open fluid inclusions. a) Electron microphotograph of an open inclusion in olivine. Talc (Tlc) and magnesite (Mgs) coat the inclusionwalls. b) Electron microphotograph of an open fluid inclusion in orthopyroxene. Tlc is distributed along the inclusion walls. A thin microcrystalline coating of gypsum, $\mathrm{KCl}, \mathrm{NaCl}, \mathrm{SiO}_{2}$, and $\mathrm{Fe}-\mathrm{Al}$ oxides is observed on talc crystals (inset). c) Qualitative EDS-EDAX chemical analysis of the coating shown in Fig. 3b (inset image). d) Main Raman modes of gypsum inside the fluid inclusion in Fig. 3b. Unlabelled peaks refer to enclosing orthopyroxene. e) $\mathrm{OH}^{-}$Raman modes of 
gypsum. Raman spectra in Fig. 3d and e were collected in the same area of EDS-EDAX analysis (inset image in 3b).

Fig. 4 - Association of fluid, and hydrous-silicate inclusions in clinopyroxene (Cpx) from hydrous peridotites. a) Photomicrograph showing trailbound fluid inclusions (f.i.) and pargasite (Prg) in Cpx in peridotites from Ethiopia. b) Photomicrograph showing trailbound fluid inclusions (f.i.) and phlogopite (Phl) in Cpx in peridotites from Sardinia. c) Back scattered electron image showing f.i. (black) and Prg (dark gray) distribution in Cpx. Spinel inclusions are also visible (white). Back scattered electron image image of f.i. (black) and $\mathrm{Phl}$ distribution in Cpx. Note that Phl and Prg inclusions have the same chemical composition as metasomatic phases in rocks.

Fig. 5 - Synchrotron FT-IR imaging of water distribution in orthopyroxene and garnet surrounding fluid inclusions. (a) Microphotograph showing fluid inclusion (f.i.) distribution in the investigated orthopyroxene area, plane polarized light. (b) Absorbance map in the 3000-3600 $\mathrm{cm}^{-1}$ region and calculated water contents in Opx (ppm). (c) Microphotograph of garnet containing fluid inclusions (f.i.), crossed polars. (e) Absorbance map in the $3000-3800 \mathrm{~cm}^{-1}$ region and relative calculated water contents in Grt ( $\mathrm{ppm})$. In FT-IR maps, the color scale is proportional to $\mathrm{OH}^{-}$enrichment (increasing from blue to pink). Measured water contents are drawn with a precision of 20's of $\mathrm{ppm} . \mathrm{Ol}=$ olivine; $\mathrm{Spl}=$ spinel.

Fig. 6 - Synchrotron FT-IR imaging of water distribution in olivine. Microphotograph of investigated area in olivine containing several fluid inclusions. b) Absorbance map in the 3000$3600 \mathrm{~cm}^{-1}$ region and calculated water contents in olivine (ppm). The color scale is proportional to $\mathrm{OH}^{-}$enrichment (increasing from blue to pink). Measured water contents are drawn with a precision of 10's of ppm. c) Qualitative distribution map of $\mathrm{OH}$ absorbance for talc and 
serpentine in the $3600-3800 \mathrm{~cm}^{-1}$ region, which allows to qualify hydrated phases in olivine. a.u.: arbitrary units.

Fig. $7-T-\mathrm{X}_{\mathrm{H} 2 \mathrm{O}}$ petrogenetic grids at $1.5 \mathrm{GPa}, 1.0 \mathrm{GPa}, 0.5 \mathrm{GPa}$, and $0.1 \mathrm{GPa}$ in the $\mathrm{MgO}-\mathrm{FeO}-$ $\mathrm{SiO}_{2}-\mathrm{H}_{2} \mathrm{O}-\mathrm{CO}_{2}$ system, calculated with En and Fo compositions at \#mg = 0.9, calculated with the thermodynamic approach of Connolly (1990). White dots are the invariant points. Black solid curves highlight possible reactions between $\mathrm{H}_{2} \mathrm{O}-\mathrm{CO}_{2}$ fluids trapped in inclusions and the surrounding magnesian orthopyroxene. All reaction equations are written such that the high- $\mathrm{X}_{\mathrm{CO} 2}$ assemblage is on the right side. The occurrence of talc as product of reactions depends on fluid pressure and on $\mathrm{X}_{\mathrm{H} 2 \mathrm{O}}($ invariant point 1), see 5.2.

Fig. $8-P-T$ petrogenetic grid at $\mathrm{X}_{\mathrm{H} 2 \mathrm{O}}=0.3$ in the $\mathrm{MgO}-\mathrm{FeO}-\mathrm{SiO}_{2}-\mathrm{H}_{2} \mathrm{O}-\mathrm{CO}_{2}$ system, calculated with En and Fo compositions at \#mg = 0.9. White dots are the invariant points. Black thick solid curves highlight possible reactions between $\mathrm{H}_{2} \mathrm{O}-\mathrm{CO}_{2}$ fluids trapped in inclusions and the surrounding orthopyroxene. All reaction equations are written such that the low- $\mathrm{X}_{\mathrm{H} 2 \mathrm{O}}$ assemblage is on the right side. The oval and the star indicate the $P-T$ conditions of fluid inclusion trapping and fluid inclusion decrepitation, respectively. The thick black arrow (a) represents the $P-T$ path of a mantle xenolith within the host lava. The dashed grey lines represent isochores of preserved (b), and decrepitated (c) fluid inclusions. The two thin black arrows represent the $P-T$ paths of preserved (high density, isochore b), and decrepitated (low density, isochore c) fluid inclusions. As evident from the grid, syn-, and post-eruptive reactions between fluid inclusions and surrounding orthopyroxene can produce hydrous minerals (talc) only in lowdensity fluid inclusions (c). 
- Raman and FTIR in fluid inclusions can verify the hydrous nature of mantle fluids.

-Shallow mantle inclusions either contain $\mathrm{H}_{2} \mathrm{O}$ or represent "dehydrated" fluids.

- Hydrous fluid inclusions carry significant amounts of $\mathrm{Si}, \mathrm{Cl}, \mathrm{S}, \mathrm{K}, \mathrm{Ca}$, and $\mathrm{Na}$.

-Solute-rich hydrous fluids may be widespread in the shallow mantle. 
Figure 2
Click here to download Figure: Fig. 2.eps

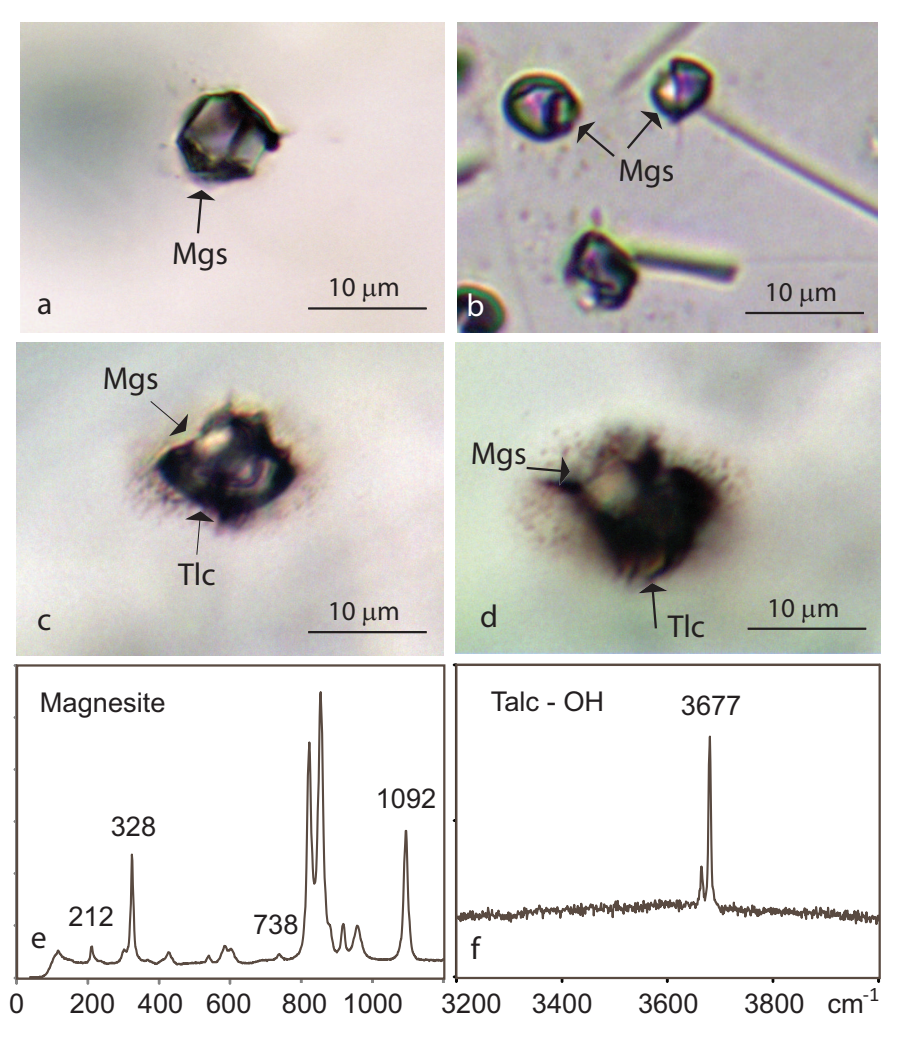



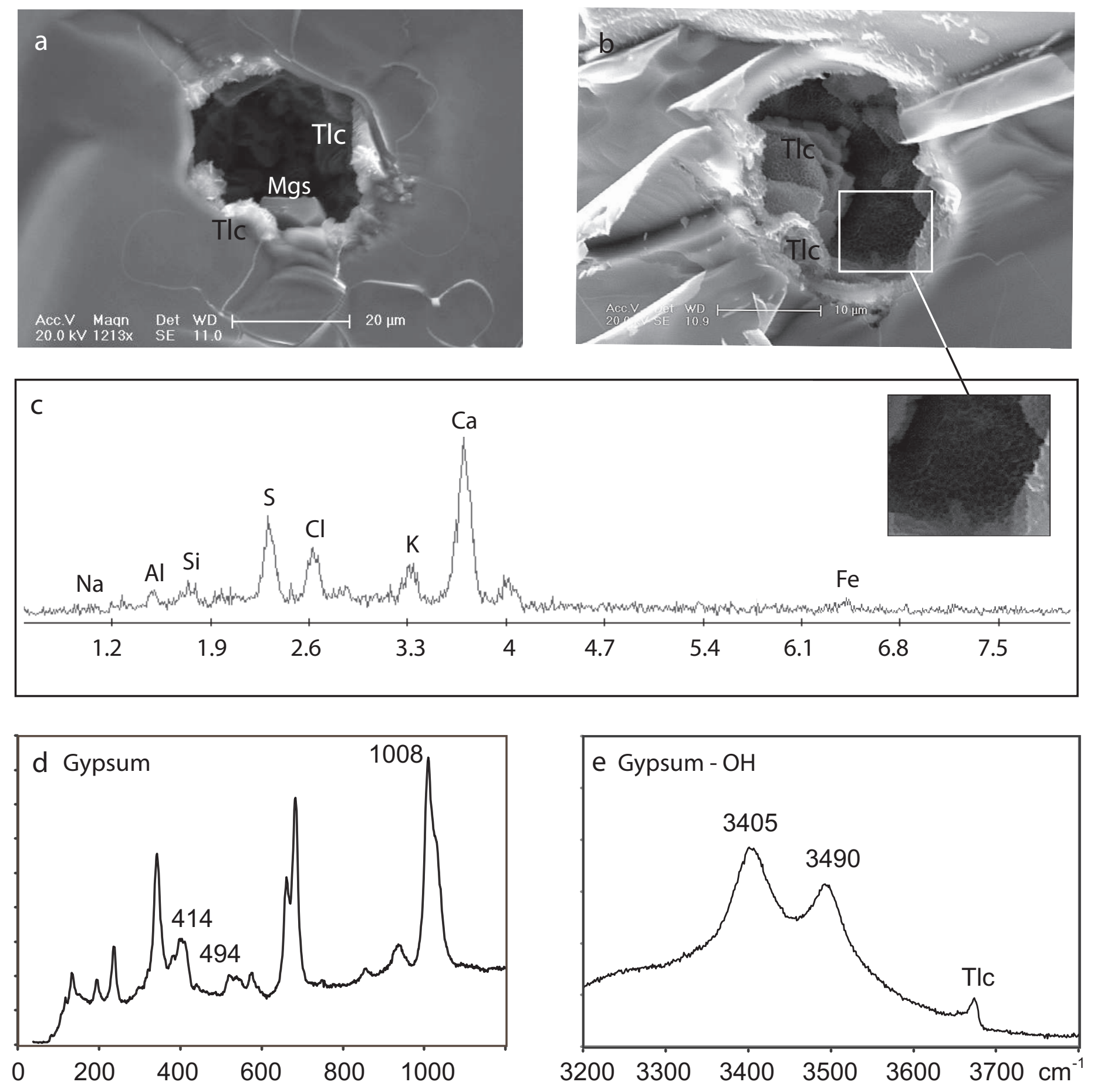
Click here to download Figure: Fig. 5.eps

$\mathrm{H}_{2} \mathrm{O}$ content in orthopyroxene
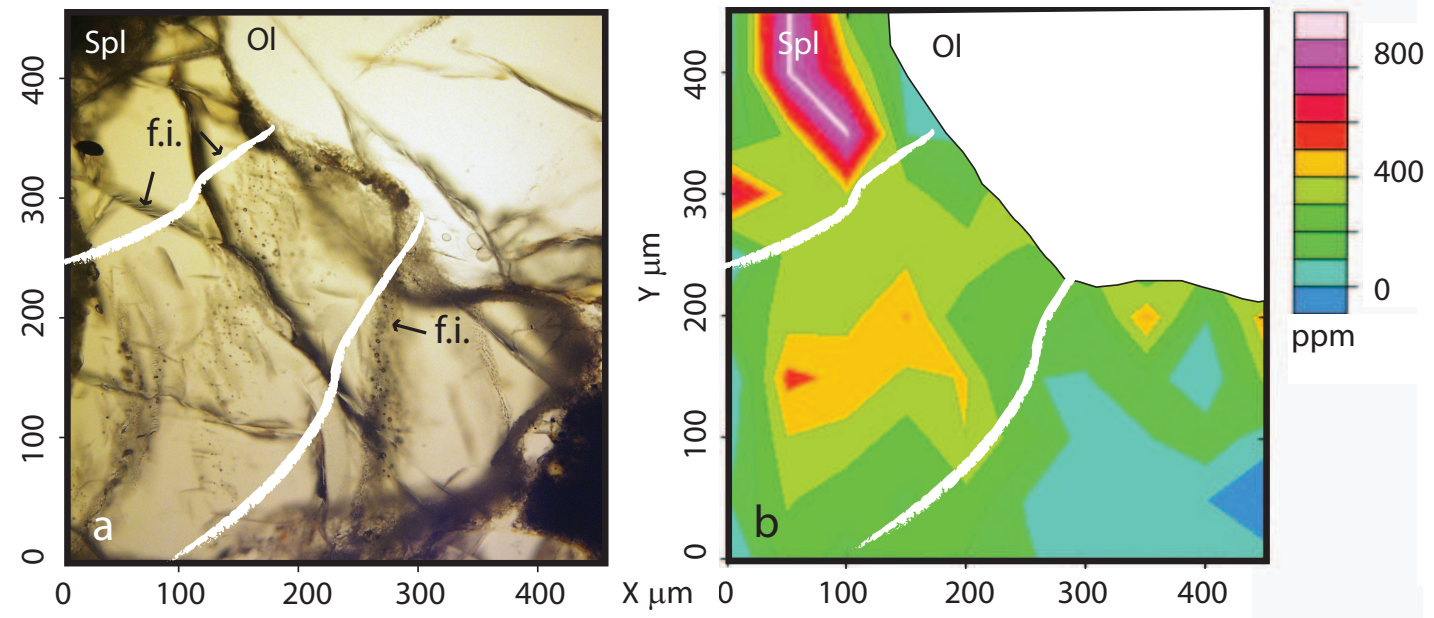

$\mathrm{H}_{2} \mathrm{O}$ content in garnet
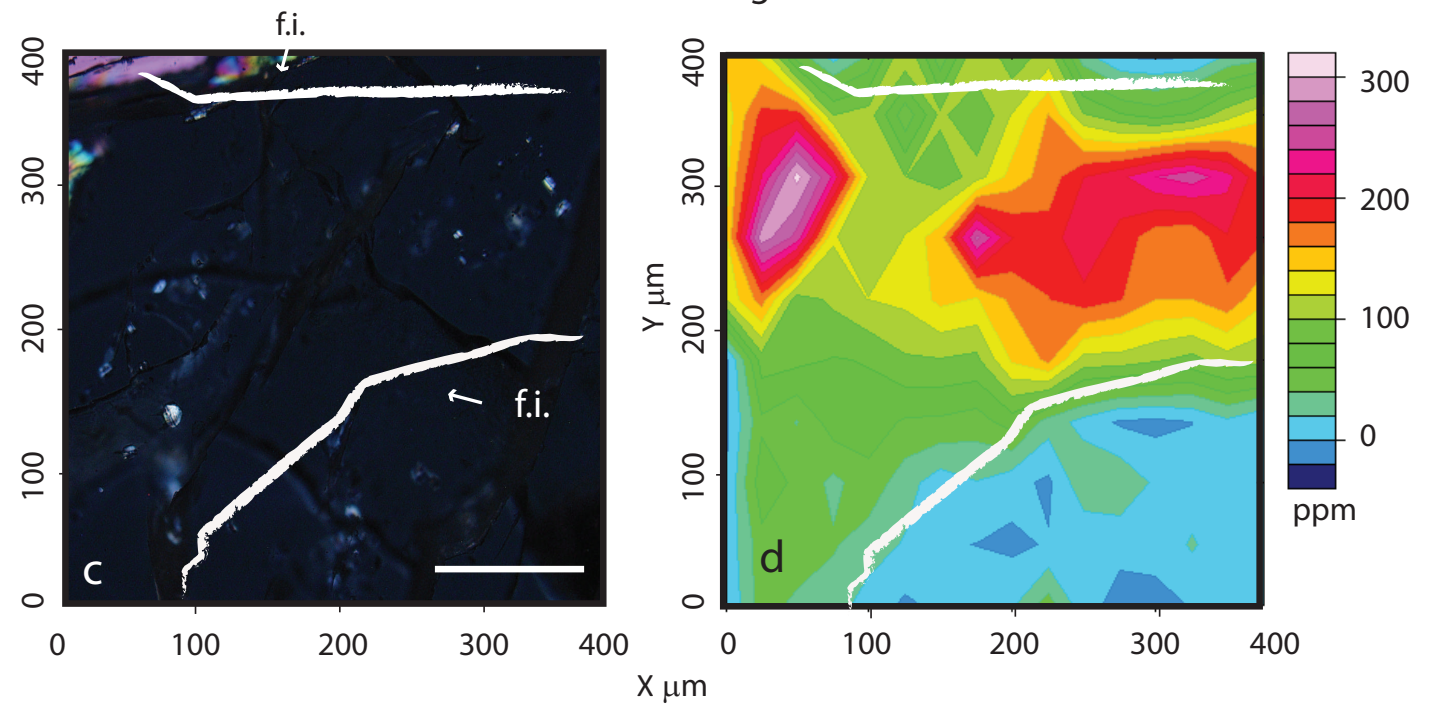
$\mathrm{H}_{2} \mathrm{O}$ content in olivine

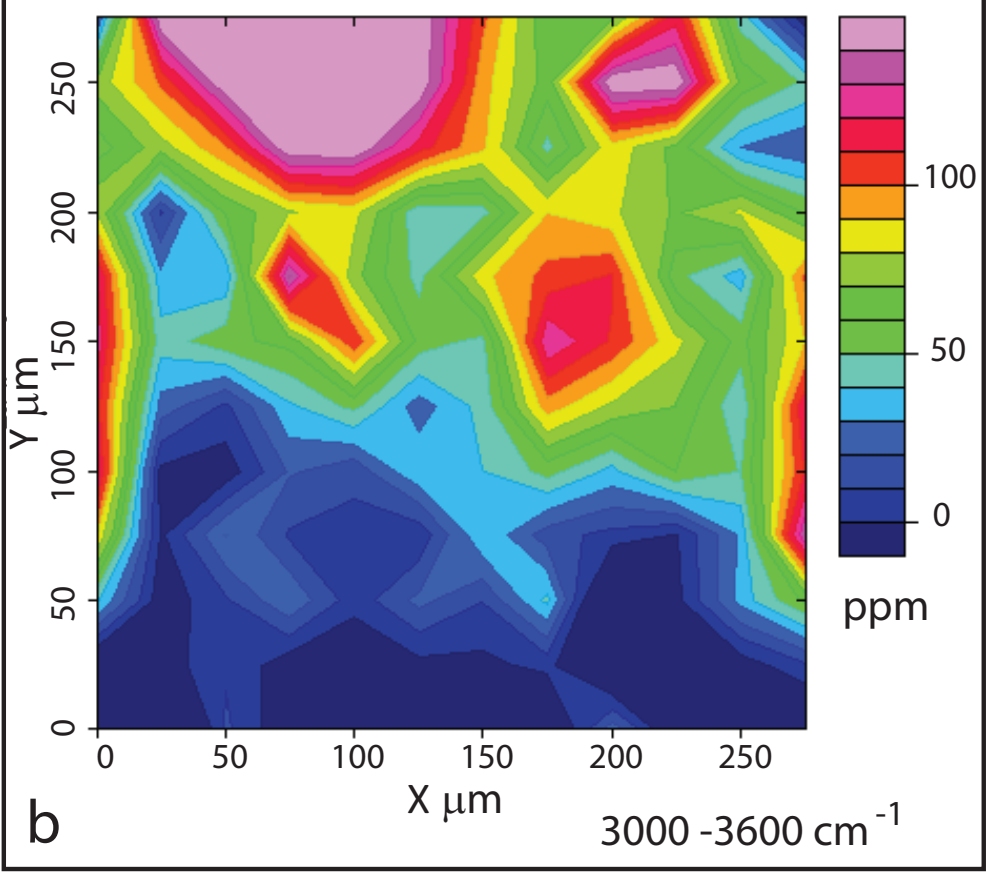

$\mathrm{OH}$ in Talc and Serpentine

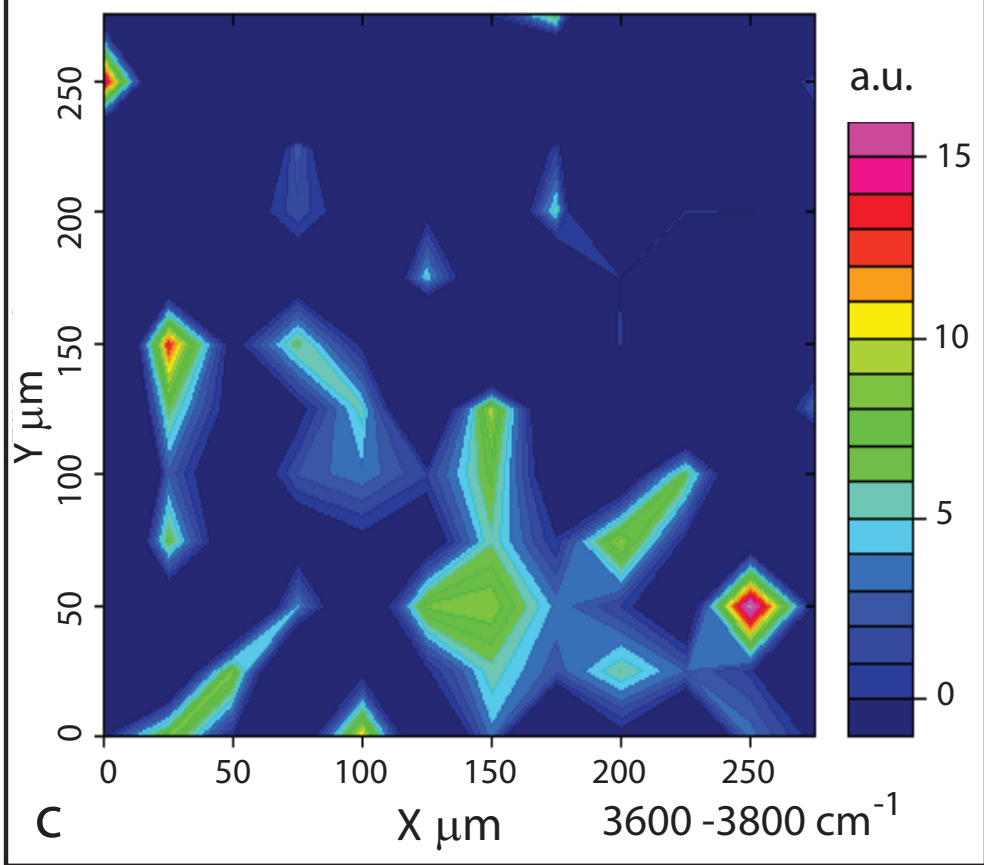



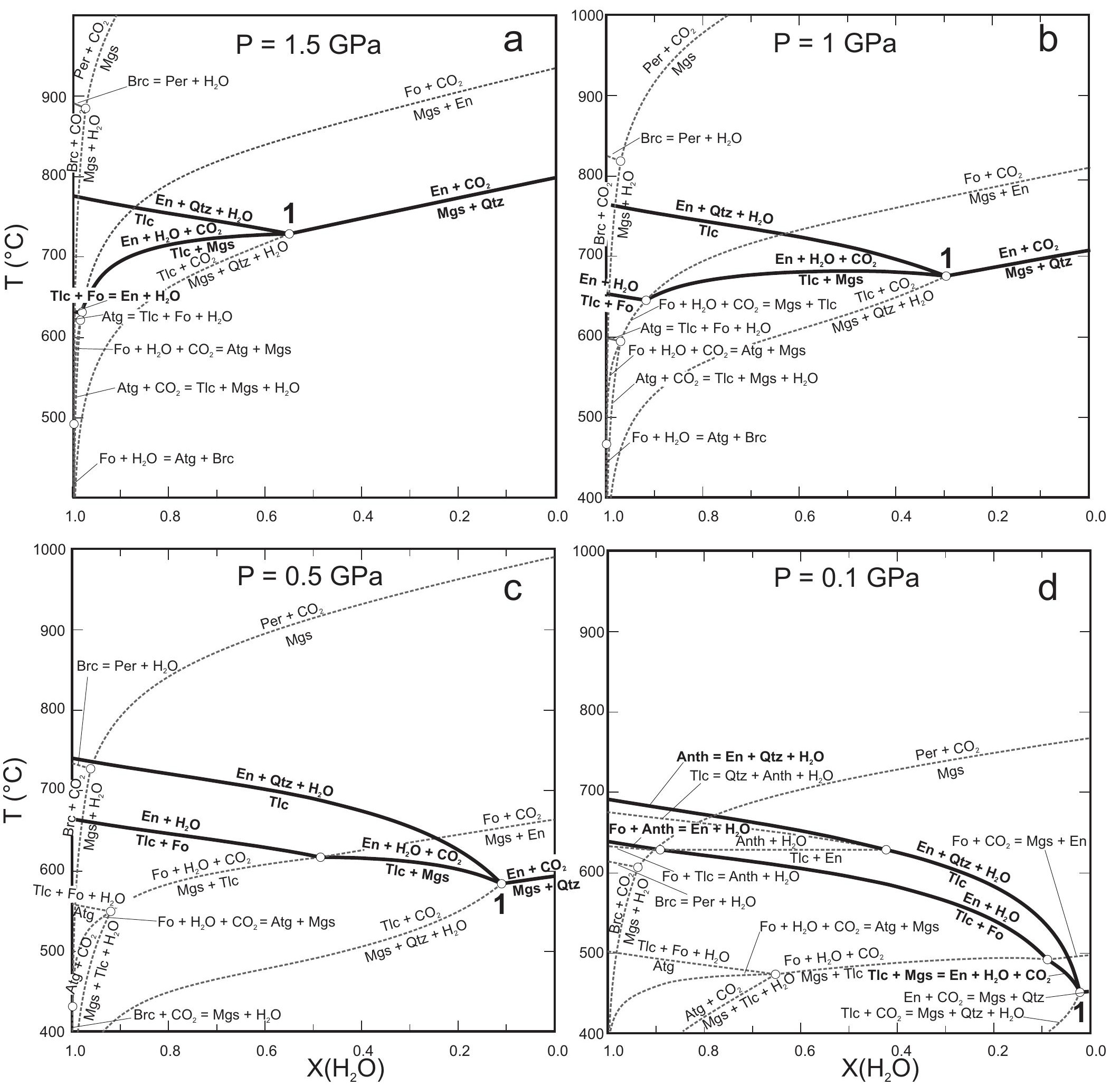
Click here to download Figure: Fig. 8.eps

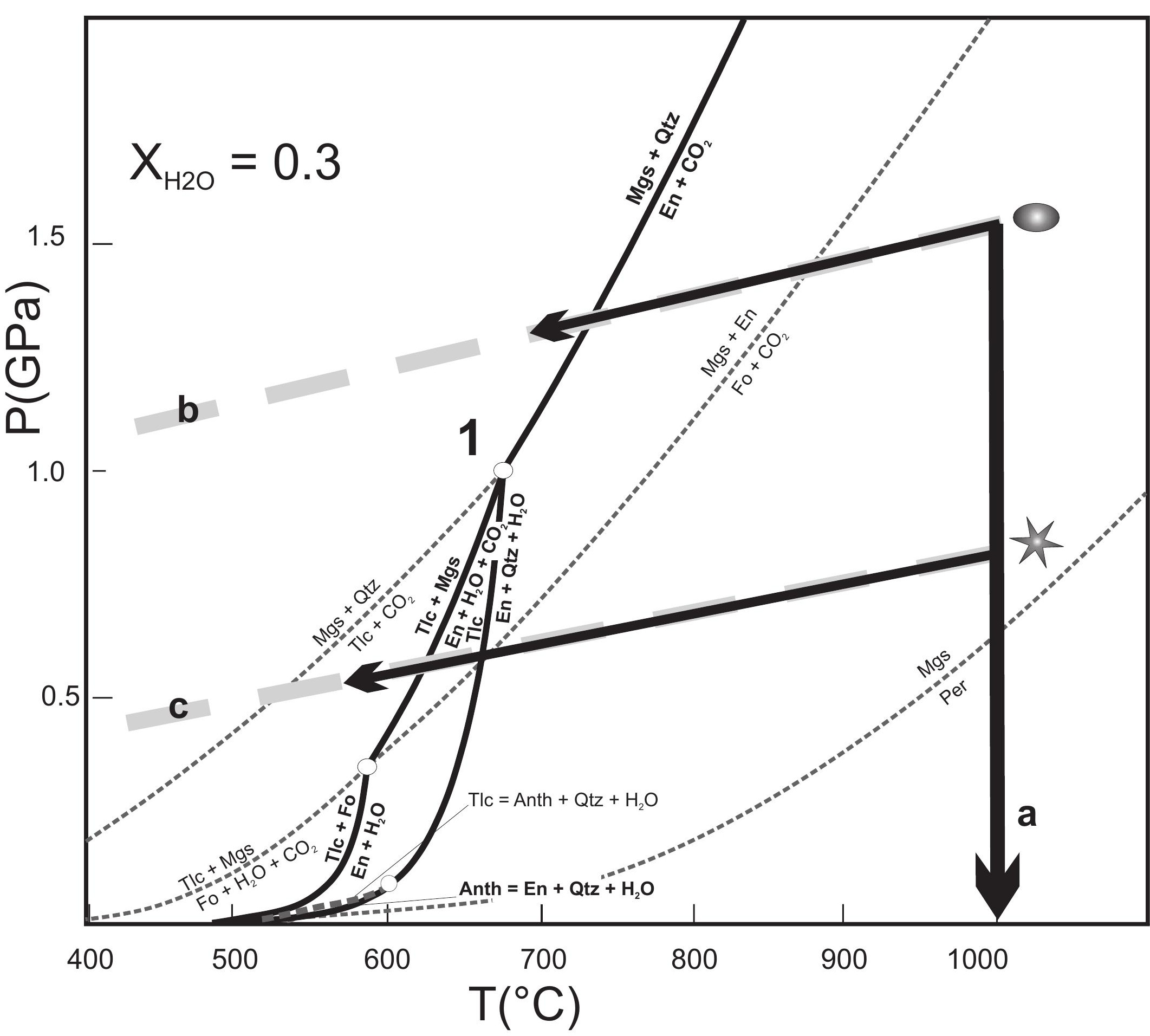


Table 1 - Sample description

\begin{tabular}{|c|c|c|c|c|c|c|c|c|c|c|c|c|}
\hline \multicolumn{6}{|c|}{ Peridotites } & \multicolumn{7}{|c|}{$\mathrm{CO}_{2}$-rich fluid inclusions } \\
\hline Locality & Host rock & $\begin{array}{c}\text { Rock type } \\
\text { ( } n^{\circ} \text { of samples) }\end{array}$ & Texture & $\begin{array}{l}\text { Mineralogy } \\
\text { (vol\%) }\end{array}$ & $\begin{array}{c}P-T \\
\text { conditions }\end{array}$ & Host & $\begin{array}{c}\mathrm{Tm}_{\mathrm{CO} 2} \\
\left({ }^{\circ} \mathrm{C}\right)\end{array}$ & $\begin{array}{c}\mathrm{ThL}_{\mathrm{CO} 2} \\
\left({ }^{\circ} \mathrm{C}\right)\end{array}$ & $\begin{array}{c}\text { Ths } \mathrm{L}_{\mathrm{cO} 2} \\
\left({ }^{\circ} \mathrm{C}\right)\end{array}$ & $\begin{array}{c}\operatorname{TsL}_{\text {co2 }} \\
\left({ }^{\circ} \mathrm{C}\right)\end{array}$ & $\begin{array}{c}\mathrm{Tm}_{\text {Clat }} \\
\left({ }^{\circ} \mathrm{C}\right)\end{array}$ & $\begin{array}{c}P \text { from } \\
\text { isochores }\end{array}$ \\
\hline $\begin{array}{l}\text { Hawaii } \\
\text { Oahu, } \\
\text { Salt Lake } \\
\text { Crater }\end{array}$ & $\begin{array}{c}\text { Honolulu } \\
\text { volcanics: } \\
\text { Alkali basalt, } \\
\text { Basanite, } \\
\text { Nephelinite } \\
\text { lavas }\end{array}$ & $\begin{array}{c}\text { Grt Pyroxenite } \\
\text { (4) }\end{array}$ & granular & $\begin{array}{c}\text { Ol (5-15) } \\
\text { Opx (5-10) } \\
\text { Cpx (65-85) } \\
\text { Grt-Spl (1-6) } \\
\text { Phl (0-traces) }\end{array}$ & $\begin{aligned} & 1000^{\circ} \mathrm{C} \\
> & 4.5 \mathrm{GPa}\end{aligned}$ & $\begin{array}{l}\text { Ol } \\
\text { Opx } \\
\text { Cpx }\end{array}$ & $\begin{array}{c}-56.8 /-56.6 \\
-56.8 /-56.6 \\
-57 /-56.6\end{array}$ & $\begin{array}{l}-56.6 / 25 \\
-56.6 / 24 \\
-56.6 / 9.8\end{array}$ & $\begin{array}{l}-57.8 /-56.6 \\
-58.2 /-56.7\end{array}$ & $\begin{array}{c}-57 /-56.5 \\
-57.9 /-50.8\end{array}$ & & $\begin{array}{l}>1.8 \mathrm{GPa} \\
>1.8 \mathrm{GPa}\end{array}$ \\
\hline $\begin{array}{l}\text { Ethiopian } \\
\text { volcanic } \\
\text { plateau, } \\
\text { Injibara }\end{array}$ & $\begin{array}{l}\text { Basanite } \\
\text { lavas }\end{array}$ & (6) & $\begin{array}{l}\text { protogranuar to } \\
\text { porphyroclastic }\end{array}$ & $\begin{array}{l}\text { Ol (50-70) } \\
\text { Opx (20-30) } \\
\text { Cpx (10-20) } \\
\text { Spl (2-7) } \\
\text { Prg (1) }\end{array}$ & $\begin{array}{c}950-1015^{\circ} \mathrm{C}^{-} \\
1.3-2 \mathrm{GPa}\end{array}$ & $\begin{array}{l}\text { Ol1 } \\
\text { Opx1 } \\
\text { Cpx }\end{array}$ & $\begin{array}{l}-57.6 /-56.5 \\
-57.6 /-56.2 \\
-57.9 /-56.3\end{array}$ & $\begin{array}{l}-30.5 / 27.3 \\
-39.2 / 30.9 \\
-33.1 / 30.9\end{array}$ & & & 5.6 & $1.4-1.5 \mathrm{GPa}$ \\
\hline $\begin{array}{l}\text { Italy } \\
\text { Sardinia, } \\
\text { Mt. Lisiri }\end{array}$ & $\begin{array}{l}\text { Álkali basalt } \\
\text { scoriae }\end{array}$ & $\begin{array}{c}\text { Spl Pyroxenite } \\
\text { (2) }\end{array}$ & granular & $\begin{array}{l}\text { Öl }(8-10) \\
\text { Opx (10-12) } \\
\text { Cpx (80-85) } \\
\text { Spl (1-4) } \\
\text { Phl (1-2) }\end{array}$ & $\begin{array}{l}950-1050^{\circ} \mathrm{C}- \\
0.9-1.5 \mathrm{GPa}\end{array}$ & Opx & $\begin{array}{c}-56.5 \\
-56.8 /-56.6 \\
-56.7 /-56.5\end{array}$ & $\begin{array}{l}-13.8 /-4.8 \\
-24 / 9.3 \\
-14 \text { / } 29.3\end{array}$ & & & & $0.95 \mathrm{GPa}$ \\
\hline & & $\begin{array}{l}\text { Spl Dunite } \\
\text { (3) }\end{array}$ & porphyroclastic & $\begin{array}{l}\text { Ol (90-95) } \\
\text { Opx (<1) } \\
\text { Cpx (1-6) } \\
\text { Spl (1-3) }\end{array}$ & & $\begin{array}{l}\text { Opx1 } \\
\text { Cpx }\end{array}$ & $\begin{array}{c}-56.6 \\
-57 /-56.6\end{array}$ & $\begin{array}{c}-11.7 / 3 \\
-27.3 / 26.1\end{array}$ & & & & $1 \mathrm{GPa}$ \\
\hline $\begin{array}{l}\text { Central Italy } \\
\text { Torre Alfina }\end{array}$ & $\begin{array}{l}\text { Lamproite } \\
\text { lavas }\end{array}$ & $\begin{array}{l}\text { Spl Harzburgite, } \\
\text { Spl Dunite } \\
(3+1)\end{array}$ & protogranular & $\begin{array}{l}\text { Opl (80-95) } \\
\text { Cpx (3-12) } \\
\text { Spl }(1-4) \\
\text { Phl }(1-10)\end{array}$ & $\begin{array}{l}950-1080^{\circ} \mathrm{C}^{-} \\
1.2-1.6 \mathrm{GPa}\end{array}$ & Opx1 & - & - & & & & $1.2 \mathrm{GPa}^{*}$ \\
\hline
\end{tabular}

$\mathrm{Ol}=$ Olivine; Opx = Orthopyroxene; $\mathrm{Cpx}=$ Clinopyroxene; $\mathrm{Spl}=$ Spinel; Grt = Garnet; Prg = Pargasite; Phl = Phlogopite; Tm = temperature of melting; ThL = temperature of homogenization to liquid; Ths = temperature of homogenization to liquid in presence of solid CO2 - superdense $\mathrm{CO} 2$ inclusions; TsL= temperature of solid $\mathrm{CO} 2$ final melting - superdense $\mathrm{CO} 2$ inclusions; $\mathrm{Hhl}=$ hydrohalite; Clat = clathrate; Ol1, Opx1 = olivine and orthpyroxene porphyroclasts; * Pressures derived from Raman CO2 density data (cf., Frezzotti et al., 2012 ). 
Table 2 - Detection of water and solutes in fluid inclusions in mantle mineral using different analytical techniques

\begin{tabular}{|c|c|c|c|c|c|c|c|c|c|}
\hline \multicolumn{4}{|c|}{ Mantle Rocks } & \multicolumn{6}{|c|}{ Water and solutes in individual fluid inclusions } \\
\hline \multirow{2}{*}{ Locality } & \multirow{2}{*}{ Rock type } & \multirow{2}{*}{$\begin{array}{l}\text { Hydrous } \\
\text { Minerals }\end{array}$} & \multirow{2}{*}{$\begin{array}{c}\text { Host } \\
\text { Mineral }\end{array}$} & \multicolumn{5}{|c|}{ Analytical technique } & \multirow[t]{2}{*}{ Fluid composition } \\
\hline & & & & Microsc. & Microther. & Raman & FT-IR & EDS Microprobe & \\
\hline \multirow[t]{3}{*}{ Canary $^{*}$} & Sp Lherz. & No & $\mathrm{Ol}$ & No & No & Talc - Magnesite & - & Talc $-\mathrm{NaCl}$ & $\mathrm{CO}_{2}$ \\
\hline & Sp Harz. & & Opx & No & No & - & - & No & + \\
\hline & & & Cpx & No & No & - & - & No & $\mathrm{H}_{2} \mathrm{O}, \mathrm{SiO}_{2}$ and $\mathrm{NaCl}$ \\
\hline \multirow[t]{4}{*}{ Hawaii } & Grt Pyrox. & No & $\mathrm{Ol}$ & No & No & $\mathrm{H}_{2} \mathrm{O}-\mathrm{CO}_{2}$ & - & No & $\mathrm{CO}_{2}$ (Carbonate melt) \\
\hline & & & Opx & No & No & $\mathrm{H}_{2} \mathrm{O}-\mathrm{CO}_{2}$ & - & - & + \\
\hline & & & Cpx & No & No & $\mathrm{H}_{2} \mathrm{O}-\mathrm{CO}_{2}$ & - & No & $\mathrm{H}_{2} \mathrm{O}, \mathrm{H}_{2} \mathrm{~S}$ and $\mathrm{N}_{2}$ \\
\hline & & & Grt & No & No & No & - & - & \\
\hline \multirow[t]{3}{*}{ Ethiopia } & Sp Lherz. & Prg & $\mathrm{Ol}$ & No & No & $\begin{array}{l}\text { Talc/Clinochlore (rare) } \\
\text { Magnesite }-\mathrm{H}_{2} \mathrm{O}-\mathrm{CO}_{2}\end{array}$ & $\mathrm{H}_{2} \mathrm{O}-\mathrm{OH}^{-}$ & Magnesite - Talc & $\mathrm{CO}_{2}$ \\
\hline & & & Opx & Yes & Yes & $\mathrm{H}_{2} \mathrm{O}-\mathrm{CO}_{2}$ & $\mathrm{H}_{2} \mathrm{O}$ & - & + \\
\hline & & & Cpx & No & No & - & No & - & $\mathrm{H}_{2} \mathrm{O}, \mathrm{SiO}_{2}, \mathrm{KCl}$ and $\mathrm{NaCl}$ \\
\hline \multirow[t]{3}{*}{ Sardinia } & Sp Pyrox. & Phl & $\mathrm{Ol}$ & No & No & Talc - Magnesite & - & $\mathrm{K}, \mathrm{Cl}, \mathrm{S}, \mathrm{Ca}, \mathrm{Na}$ & $\mathrm{CO}_{2}$ \\
\hline & Sp Dun. & & Opx & No & No & Talc (rare) - Magnesite & - & $\mathrm{K}, \mathrm{Cl}, \mathrm{S}, \mathrm{Ca}, \mathrm{Na}$ & + \\
\hline & & & Cpx & No & No & $\begin{array}{c}\text { Gypsum (rare) Dolomite - } \\
\text { Talc (rare) }\end{array}$ & - & - & $\mathrm{H}_{2} \mathrm{O}, \mathrm{SiO}_{2}, \mathrm{KCl}, \mathrm{NaCl}, \mathrm{CaSO}_{4}$ \\
\hline \multirow{2}{*}{$\begin{array}{c}\text { Central } \\
\text { Italy }\end{array}$} & Sp Harz. & $\mathrm{Phl}$ & Opx & No & No & $\mathrm{H}_{2} \mathrm{O}-\mathrm{CO}_{2}-\mathrm{S}_{8}$ & - & - & $\mathrm{CO}_{2}+\mathrm{H}_{2} \mathrm{O}$ and $\mathrm{S}$ \\
\hline & Sp Dun. & & Cpx & No & No & No & - & - & \\
\hline
\end{tabular}

$\mathrm{Ol}=$ Olivine; Opx = Orthopyroxene; Cpx = Clinopyroxene; $\mathrm{Sp}=$ Spinel; Grt = Garnet; Prg = Pargasite; Phl = Phlogopite; Lherz. = Lherzolite; Harz. = Harzburgite; Dun. $=$ Dunite; Pyrox. = Pyroxenite; f.i. = Fluid inclusions; Microsc. = Microscopy; Microther. $=$ Microthermometry; $-=$ not analyzed. ${ }^{*}$ data from Frezzotti et al., 2002a. 